\title{
Analysis of Urban Heat Island and Heat Waves Using Sentinel-3 Images: a Study of Andalusian Cities in Spain
}

\author{
David Hidalgo García ${ }^{1}$ (iD
}

Received: 13 July 2021 / Revised: 19 October 2021 / Accepted: 20 October 2021 / Published online: 2 November 2021

(c) The Author(s) 2021

\begin{abstract}
At present, understanding the synergies between the Surface Urban Heat Island (SUHI) phenomenon and extreme climatic events entailing high mortality, i.e., heat waves, is a great challenge that must be faced to improve the quality of life in urban zones. The implementation of new mitigation and resilience measures in cities would serve to lessen the effects of heat waves and the economic cost they entail. In this research, the Land Surface Temperature (LST) and the SUHI were determined through Sentinel-3A and 3B images of the eight capitals of Andalusia (southern Spain) during the months of July and August of years 2019 and 2020. The objective was to determine possible synergies or interaction between the LST and SUHI, as well as between SUHI and heat waves, in a region classified as highly vulnerable to the effects of climate change. For each Andalusian city, the atmospheric variables of ambient temperature, solar radiation, wind speed and direction were obtained from stations of the Spanish State Meteorological Agency (AEMET); the data were quantified and classified both in periods of normal environmental conditions and during heat waves. By means of Data Panel statistical analysis, the multivariate relationships were derived, determining which ones statistically influence the SUHI during heat wave periods. The results indicate that the LST and the mean SUHI obtained are statistically interacted and intensify under heat wave conditions. The greatest increases in daytime temperatures were seen for Sentinel-3A in cities by the coast $\left(\mathrm{LST}=3.90{ }^{\circ} \mathrm{C}, \mathrm{SUHI}=1.44{ }^{\circ} \mathrm{C}\right)$ and for Sentinel-3B in cities located inland $\left(\mathrm{LST}=2.85{ }^{\circ} \mathrm{C}\right.$, SUHI $=0.52^{\circ} \mathrm{C}$ ). The existence of statistically significant positive relationships above $99 \%(p<0.000)$ between the SUHI and solar radiation, and between the SUHI and the direction of the wind, intensified in periods of heat wave, could be verified. An increase in the urban area affected by the SUHI under heat wave conditions is reported.
\end{abstract}

David Hidalgo García

dhidalgo@ugr.es

1 Technical Superior School of Building Engineering, University of Granada, Fuentenueva Campus,

18071 Granada, Spain 


\section{Graphical Abstract}

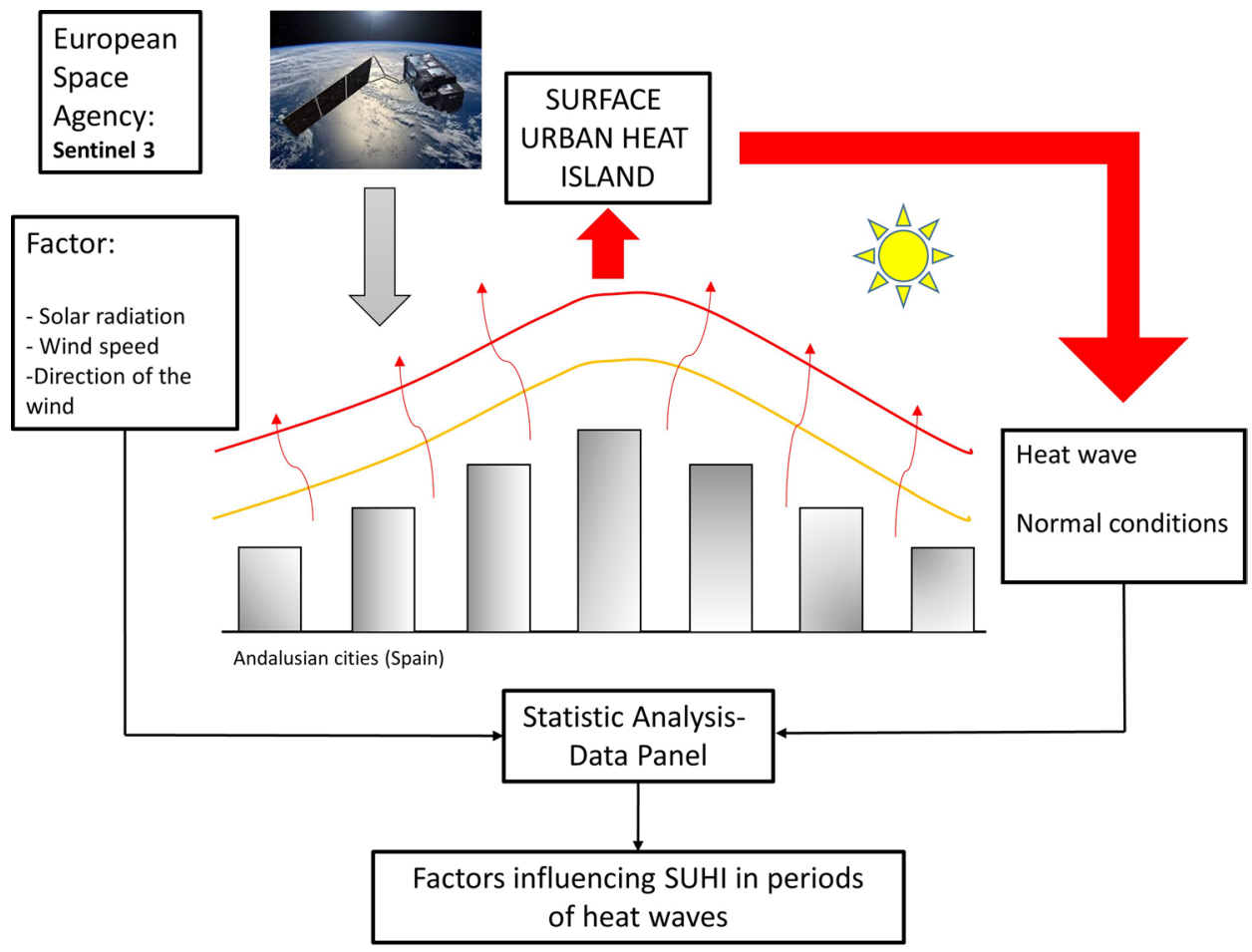

Keywords Surface Urban Heat Island · Heat waves · Sentinel-3 imagery · Land surface temperature · Heat Resilience and Urban Resilience

\section{Introduction}

In recent decades, numerous studies warn that the transformation of the landscape owing to the expansion of urban areas is one of the processes that contributes most to climate change (Li et al. 2011; Carvalho et al. 2017; Jiang et al. 2019; Yang et al. 2019; Song et al. 2020). Changes in land cover increase the surfaces of impermeable materials, such as asphalt and concrete, reducing evapotranspiration (Stewart and Oke 2012). These materials are known to store the heat coming from solar radiation and subsequently release it into the atmosphere (Arnfield 2003; Zhou et al. 2015; An et al. 2020).

The greatest increases in temperature occur in cities, mainly due to a phenomenon of urban climate alteration (Li et al. 2011; Zhou et al. 2015; Wang et al. 2016; Luo and Lau 2018; Zhao et al. 2018; Tewari et al. 2019; Anjos et al. 2020) called Urban Heat Island (UHI), whose intensity is heightened by multiple human activities (Lai et al. 2018; Huang et al. 2020; Santamouris 2020) and by extreme weather events such as droughts or heat waves. The positive interaction between UHI and heat waves is well documented: in Baltimore and Maryland ( $\mathrm{Li}$ and
Bou-Zeid 2013), Beijing (Li et al. 2015; Jiang et al. 2019), New York (Ramamurthy and Bou-Zeid 2017), Shanghai and Guangzhou (Jiang et al. 2019) and Athens (Founda and Santamouris 2017).

Research shows that heat waves are becoming more intense, lasting longer, and occurring more frequently (Meehl and Tebaldi 2004; Sun et al. 2014). It is anticipated that by the end of the twenty-first century they will affect larger land areas (Meehl and Tebaldi 2004; Lau and Nath 2012; Coumou et al. 2013). Episodes of increased anthropogenic heat are known to be among the natural phenomena having the greatest social, economic and environmental impact (An et al. 2020). They imply more consumption of electricity and water in homes (Valor et al. 2001), and increased morbidity and mortality (Semenza et al. 1996; Poumadère et al. 2005; Jiang et al. 2019; An et al. 2020). Proof can be found in the heat wave of Chicago in 1995, which caused 800 deaths (Semenza et al. 1996), that of the summer of 2003 in Europe, when 70,000 people died (Robine et al. 2008), the one occurring in Russia during the summer of 2010 (Grumm 2011), that of eastern China in 2013 (Xia et al. 2016), or Northwestern USA and Western Canada (Lytton) in 2021, with temperatures over 
$45.0{ }^{\circ} \mathrm{C}$ on consecutive days and extremely warm nights in between, causing some 500 deaths (UNO 2021).

While a positive interaction between SUHI and heat waves has been demonstrated, the type of climate or particular climatic conditions (wind speed and direction, solar radiation) and geomorphological factors of cities are contribute substantially to this interaction (Zhao et al. 2014; Yoon et al. 2018; Jiang et al. 2019; An et al. 2020; Qiu et al. 2020; Venter et al. 2020). Studies of cities in Oklahoma (Basara et al. 2010), several European cities (Founda et al. 2015), London (Gregor et al. 2007) or Beijing and Guangzhou (Jiang et al. 2019) report increases in SUHI that are stronger during the night. In contrast, studies of Athens and Parma (House and Santamouris 2011) and Shanghai (Ao et al. 2019; Jiang et al. 2019) found that the SUHI rise was stronger during the day. Other studies found no significant amplification of the SUHI (Ramamurthy and Bou-Zeid 2017; Scott et al. 2018; Zhao et al. 2018).

Among the different methodologies used to determine this phenomenon, thermal remote sensing stands out because of its capacity to allow large-scale urban studies of LST and SUHI using satellite images with Thermal Infrared Sensor (TIRS) sensors. Studies involving these systems and the dynamics of urban climate have become consolidated as an important field of research (Ramamurthy and BouZeid 2017) with an extensive body of literature (Wang and Ouyang 2017; Song et al. 2018; Yao et al. 2018; Sejati et al. 2019; Guo et al. 2020; Hu et al. 2020; Roy et al. 2020; Shafizadeh et al. 2020; Yang et al. 2020a). A relatively recent but highly accurate product used in many studies is Sentinel-3 imaging. All Sentinels have 3 TIRS channels-bands 7, 8 and 9-that provide LST estimates at a resolution of $1000 \mathrm{~m}$. Their use for this type of research lends an important advantage over satellites such as Landsat or NOAA, since they orbit twice a day over the same point on the planet-once during the day and again at night. The use of Sentinel-3 is widely documented in the literature, e.g., through SUHI studies of the cities of Daman (India) and Huazhaizi (China) (Yang et al. 2020b), Oklahoma City (USA) and Dahra (Senegal) (Sobrino et al. 2016).

The space-time variability of the SUHI in cities under Heat Wave conditions is largely unknown, and very few studies have focused on cities in the Mediterranean Basin. Recent estimates are that the mean air temperature will be $1-3{ }^{\circ} \mathrm{C}$ higher in the near future (compared to 1961-1990), $3-5{ }^{\circ} \mathrm{C}$ higher by the middle of the century (2040-2069) and approximately $3.5-7{ }^{\circ} \mathrm{C}$ higher by the end of the century (2070-2100) (Founda et al. 2015; Founda and Santamouris 2017); values for the Mediterranean Sea basin may be even higher (Ward et al. 2016; Cramer et al. 2018).

The fact that temperature in the Mediterranean region is increasing at a faster rate than elsewhere in the world leads it to be considered an area of high vulnerability due to climate change. Such potentially dire circumstances, together with the variability of the data, accentuate the need for detailed research efforts. In this case, a quantitative and systematic study of the existence of synergies between SUHI and heat waves in the cities of Andalusia (Spain) was undertaken.

This adverse meteorological phenomenon is a problem that tends to affect urban populations in particular. The synergies between SUHI and heat waves may be questioned, however, owing to disparate results reported to date, and insufficient knowledge about the factors affecting their intensity, properties, and activation flow. Such information is crucial for the establishment of adequate mitigation or resilience measures for urban planning in attempts to limit the effects and economic cost of heat waves (Emmanuel and Krüger 2012). This research aims to analyze the relationship between heat wave and three outstanding factors: solar radiation, wind speed and direction.

Our study was intended to characterize and quantify the variability of the LST and the day and night SUHIs of all eight Andalusian (southern Spain) capital cities using Sentinel-3 images, throughout the months of July and August of 2019 and 2020, when five heat waves occurred. The factors involved were statistically analyzed using the Data Panel method. The methodology entailed an open source environment allowing one to monitor SUHI the variations in a precise, urgent and economic way, providing for a more comprehensive understanding of the space-time variability of the SUHI during Heat Wave periods, and of underlying factors.

\section{Materials and Methods}

\subsection{Study Area and Data Source}

The area under study comprises the eight provincial capitals of the region of Andalusia, located in southern Spain (Fig. 1).

Four of them are inland cities: Sevilla, Cordoba, Granada and Jaen. The other four are coastal cities: Huelva, Cadiz, Málaga and Almería. Characteristics of the population, surface area, climate, rainfall, altitude and UTM coordinates are found in Table 1.

According to Spain's National Institute of Statistics (INE), Andalusia covers an area of $87,268 \mathrm{~km}^{2}$ and has a population of $8,427,325$, being the second largest region and the most populated one in all of Spain. The region shows different local background climates. According to the Koppen-Geiger climate classification, the cities of Cadiz and Huelva share a Mediterranean Oceanic climate (Csb), the cities of Sevilla, Malaga, Cordoba and Jaen feature a Mediterranean climate (Csa), and Granada 


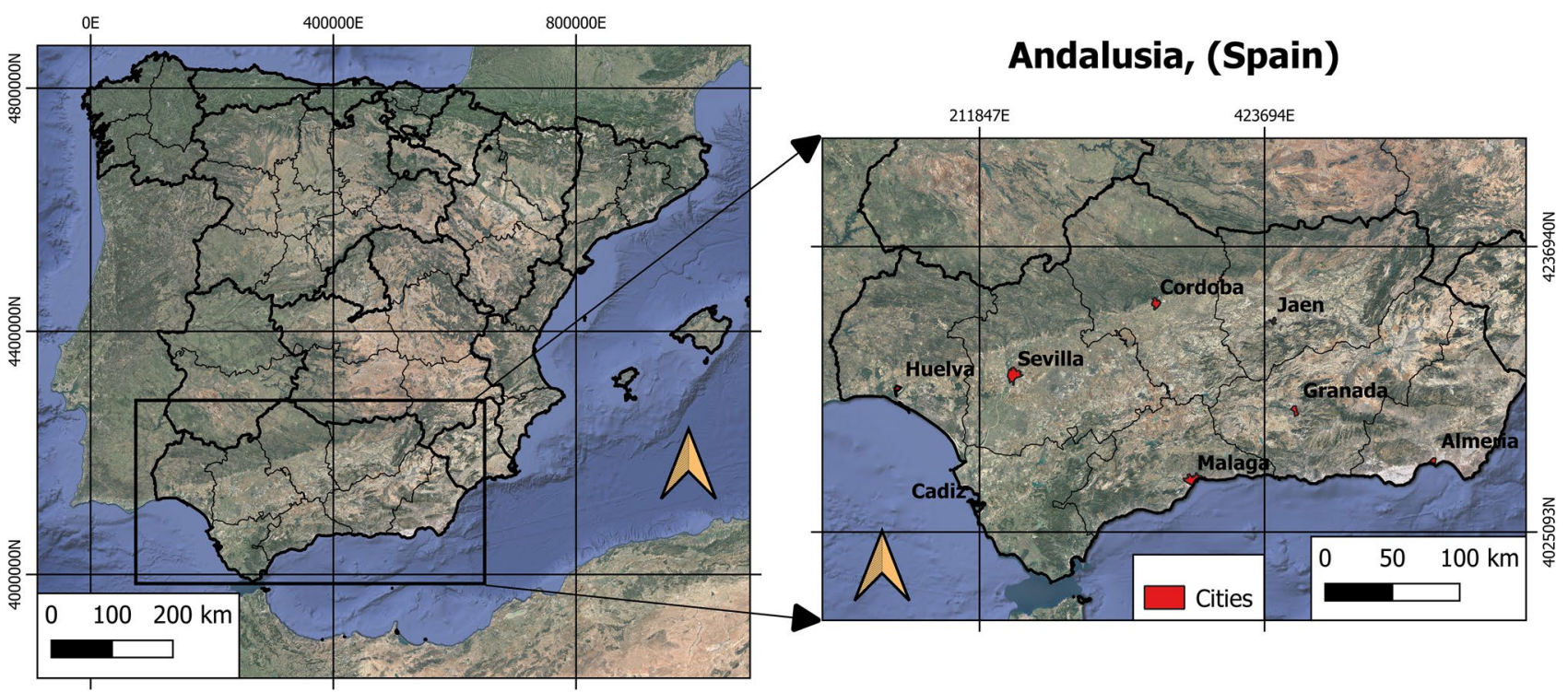

Fig. 1 Study area, Andalusia, Spain

Table 1 Characteristics of inland cities of Andalusia

\begin{tabular}{|c|c|c|c|c|c|c|c|c|}
\hline \multirow{2}{*}{$\begin{array}{l}\text { Geographic informa- } \\
\text { tion }\end{array}$} & \multicolumn{4}{|l|}{ Inland cities } & \multicolumn{4}{|l|}{ Coastal cities } \\
\hline & Sevilla & Cordoba & Jaen & Granada & Huelva & Cadiz & Malaga & Almeria \\
\hline $\begin{array}{l}\text { Downtown location } \\
\text { UTM }\end{array}$ & $\begin{array}{c}37.375 \mathrm{~N},- \\
6.025 \mathrm{~W}\end{array}$ & $\begin{array}{l}37.891 \mathrm{~N} \\
-4.819 \mathrm{~W}\end{array}$ & $\begin{array}{l}37.780 \mathrm{~N},- \\
3.831 \mathrm{~W}\end{array}$ & $37.111 \mathrm{~N},-3.362 \mathrm{~W}$ & $\begin{array}{c}37.270 \mathrm{~N},- \\
6.974 \mathrm{~W}\end{array}$ & $\begin{array}{c}36.516 \mathrm{~N},- \\
6.317 \mathrm{~W}\end{array}$ & $\begin{array}{c}36.765 \mathrm{~N},- \\
4.564 \mathrm{~W}\end{array}$ & $\begin{array}{l}36.841 \mathrm{~N},- \\
2.492 \mathrm{~W}\end{array}$ \\
\hline Climate Zone & Csa & Csa & Csa & Csa-Bsk & $\mathrm{Csb}$ & $\mathrm{Csb}$ & Csa & Bsk \\
\hline Mean annual T. $\left({ }^{\circ} \mathrm{C}\right)$ & 18.6 & 17.8 & 16.9 & 15.5 & 17.8 & 17.9 & 18.4 & 17.9 \\
\hline $\begin{array}{l}\text { Average annual rain- } \\
\text { fall }(\mathrm{mm})\end{array}$ & 576 & 612 & 552 & 450 & 467 & 597 & 520 & 228 \\
\hline Total area $\left(\mathrm{km}^{2}\right)$ & 140.8 & 1253 & 424 & 88.8 & 151.3 & 13.3 & 398 & 296.2 \\
\hline Total urban area $\left(\mathrm{km}^{2}\right)$ & 68.69 & 31.35 & 9.43 & 21.78 & 14.87 & 7.34 & 58.6 & 14.95 \\
\hline $\begin{array}{l}\text { Population in } 2019 \\
\text { (hab) }\end{array}$ & 688,592 & 325,701 & 112,999 & 232,462 & 143,663 & 116,027 & 574,654 & 198,533 \\
\hline $\begin{array}{l}\text { Urban mean elevation } \\
\text { (masl) }\end{array}$ & 11 & 106 & 570 & 680 & 24 & 13 & 8 & 16 \\
\hline
\end{tabular}

Climate Zones: Csa Mediterranean Climate, Cs $b$ Mediterranean Oceanic Climate, Bsk Cold Semi-Arid Climate

and Almería have a cold semi-arid climate (Bsk). Such typologies imply mild, humid winters and hot, dry summers (De Castro et al. 2007). The region is bordered by mountains to the north, while the Mediterranean Sea lies to the south. This circumstance makes the sea and land breezes strongly impact coastal cities. The average altitude is $503 \mathrm{~m}$ above sea level; the annual average temperature fluctuates between $11^{\circ} \mathrm{C}$ in January and $26.5^{\circ} \mathrm{C}$ in July, with minima in winter of $-3{ }^{\circ} \mathrm{C}$ and extremes in summer of $44{ }^{\circ} \mathrm{C}$. The approximate number of hours of sunshine per year ranges between 2800 and 3200, giving an average between 7.67 and $8.76 \mathrm{~h}$ of sunshine per day, depending on the area within the Andalusian region.

\subsection{Methodology}

The methodology carried out in this research called for obtaining the LST using Sentinel-3 images and validating them by comparison with the ambient temperatures recorded by AEMET (Srivastava et al. 2009; Gallo et al. 2011; Li et al. 2013; Avdan and Jovanovska 2016; Rongali et al. 2018). They were classified in periods of normal environmental conditions and in periods under heat wave. Next, the LST and SUHI values were obtained for statistical analysis, as seen in Fig. 2 .

The Data Panel statistical method was used for data analysis. Unlike more traditional methods of analysis, it admits a greater number of data, including the individual 
Fig. 2 Methodology of our research

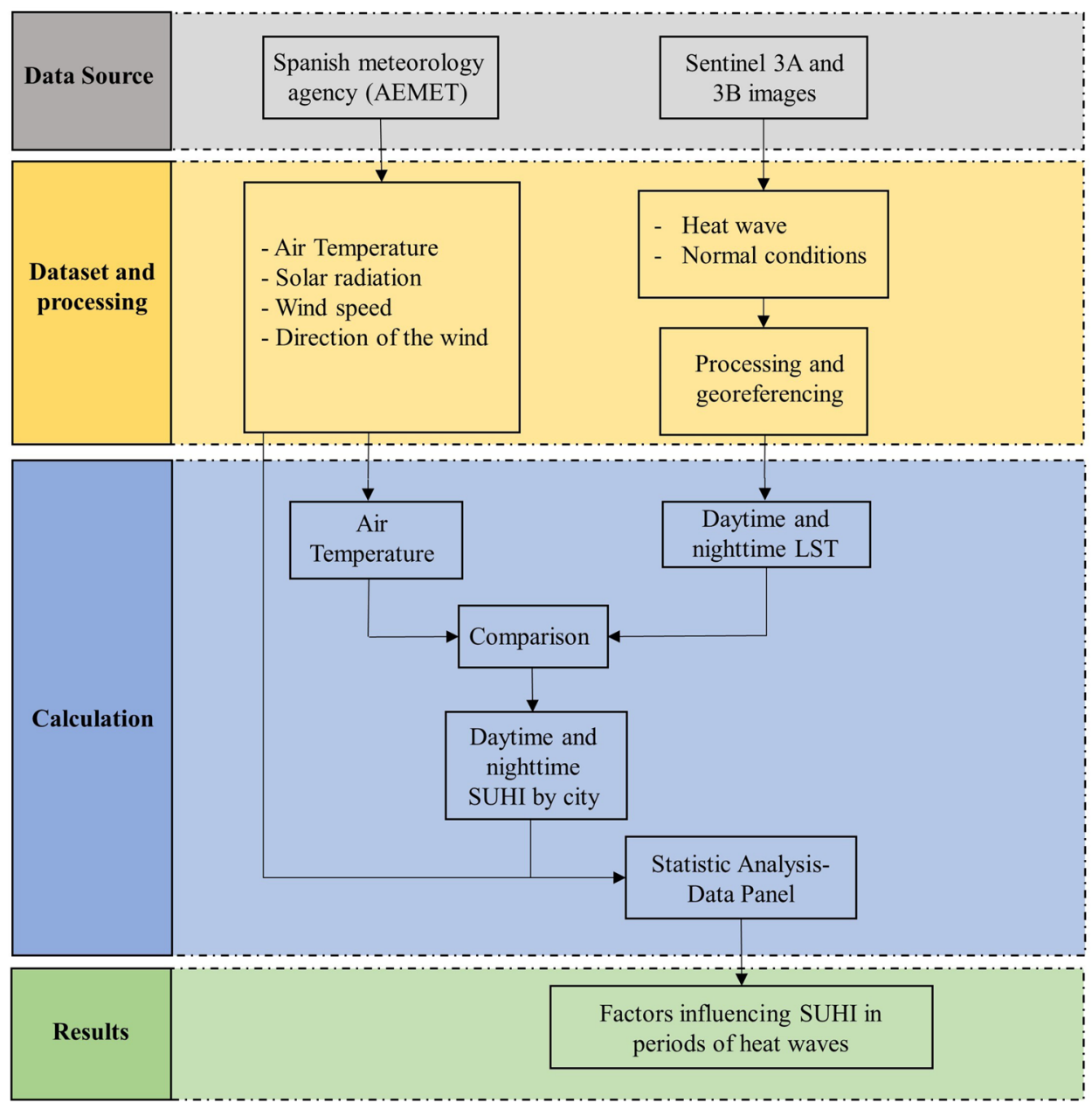

effects of each city in the overall result, while eliminating the problem of collinearity between variables. Using this method allowed us to reflect possible variations in the conditions of each city contemplated in the final results, which makes it a unique and powerful approach. It has been validated by studies (Chen et al. 2011; Alcock et al. 2015; Fang and Tian 2020) similar to ours, accounting for time series of multiple cities or areas, as well as quantitative variables when the conditions may vary among the cities analyzed.

\subsection{Identification of Heat Waves}

According to the AEMET, during 2019 three episodes classified as heat waves in Andalusia, and in 2020 just two. Table 2 indicates their onset, end date and duration, along with the thermal anomaly they produced in room temperature and the maximum temperature reached. Although numerous studies cite decreased environmental pollution, LST and SUHI as a consequence of the lockdown situation caused by COVID-19 (Ali et al. 2021; Das et al. 2021;
Table 2 Characteristics of the heat waves studied in Andalusia

\begin{tabular}{lllllll}
\hline Heat waves & \multicolumn{2}{l}{2019} & & & 2020 \\
\cline { 2 - 3 } \cline { 6 - 7 } & 1 st & 2nd & 3rd & & 4th & 5th \\
\hline Start date & $26 / 06 / 2019$ & $20 / 07 / 2019$ & $06 / 08 / 2019$ & & $30 / 07 / 2020$ & $05 / 08 / 2020$ \\
End date & $01 / 07 / 2019$ & $25 / 07 / 2019$ & $10 / 08 / 2019$ & & $01 / 08 / 2020$ & $08 / 08 / 2020$ \\
Duration (days) & 6 & 6 & 5 & & 3 & 4 \\
Air thermal anomaly (C) & 4 & 2 & 3.3 & & 4 & 5 \\
$\begin{array}{l}\text { Maximum air temperature } \\
\text { reached (C) }\end{array}$ & 38.8 & 36.8 & 37.9 & & 38.5 & 39.4 \\
\hline
\end{tabular}

Source: State Meteorological Agency (AEMET) 
Ghosh et al. 2020; Jiang et al. 2021; Mandal and Pal 2020; Nakajima et al. 2021; Pani et al. 2020; Srivastava et al. 2021; Toro et al. 2021), no scientific evidence stands to indicate a decrease in heat waves due to or during this situation.

To facilitate comparison of the LST and SUHI of periods under heat wave conditions with periods of "normal" environmental conditions, the 2 days before and after each heat wave period were taken into account. In total, the environmental parameters of the eight cities were studied for 20 days under normal conditions and 24 days under heat wave conditions.

\subsection{Sentinel-3 Images. Land Surface Temperature Estimation}

Sentinel-3 satellites are equipped with the high-resolution scanning instrument LST Radiometer, enabling LSTs of the Earth's surface to be obtained. Its thermal products have three levels of processing (levels 0,1 and 2), although only the last two are available for download. Those of level 1 present radiance and brightness temperatures that require split window (SW) algorithms to obtain the LST. Level 2 products directly and automatically include the LST together with associated parameters such as the Normalized Vegetation Index (NDVI), Vegetation Type (Biome), Vegetable Fraction (Pv) and Normalized Difference Index (NDBI).

The existing SW algorithms that serve to gauge LST are based on the concept of differential absorption (McMillin 1975), whereby the difference between the two TIRS band wavelengths allows for correction of the atmospheric effects produced on the signal. Abundant studies report on the validation, use and precision of these algorithms in Sentinel-3 images (Coppo et al. 2010; Wan 2013; Ruescas et al. 2016; Sobrino et al. 2016; Prikaziuk and van der Tol 2019; Chiang and Ivan 2020; Yang et al. 2020b).

The SW algorithm of the official Sentinel-3A and 3B level 2 SLSTR product implicitly incorporates soil emissivity by means of the following equation (Remedios and Emsley 2012):

$L S T=a_{f, i, p w}+b_{f, i}\left(T_{11}-T_{12}\right)^{\frac{1}{\cos \left(\frac{\theta}{m}\right)}}+\left(b_{f, i}+c_{f, i}\right) T_{12}-273.15$,

where LST is the surface temperature in degrees $\mathrm{C} ; \mathrm{a}, \mathrm{b}$ and $\mathrm{c}$ are coefficients dependent on the vegetation cover and the biome; and $\mathrm{T}_{11}$ and $\mathrm{T}_{12}$ are the brightness temperatures of bands 8 and 9 of Sentinel-3, respectively. $\theta$ is the zenith angle of view of the satellite and $\mathrm{m}$ is a dependent variable of $\theta$ (Remedios and Emsley 2012; Yang et al. 2020a).

Andalusia lies below the route of the Sentinel-3A and 3B satellites. The usual daytime hours of passage over the region are between 9:00 and 11:00 a.m.; nighttime passage is between 20:00 and 22:00 h (8:00-10:00 p.m.). The images chosen for the study correspond to 44 days in the months of July and August of 2019 and 2020. Throughout this time interval, a total of 88 images were used, 44 corresponding to Sentinel-3A (day) and 44 corresponding to Sentinel-3B (night). All of them have a cloudiness index of less than 15\% to ensure accuracy in obtaining the LST and subsequently calculate the SUHI. The images used were acquired through the European Space Agency (ESA) Copernicus Open Access Hub for level 2.

After downloading the images, they were reclassified and corrected using the Toolbox (S3TBX) under the Sentinel Application Platform (SNAP) open-source software environment, version 7.0.0. With the help of SNAP 7.0.0 and using level 2 products, the day and night LST of each investigated day were recovered for each city. The LST images were subsequently exported in Geotiff format to QGIS open-source software, version 3.10.5.

\subsection{Rural Stations and Meteorological Data}

The ambient temperature was obtained from AEMET. This national weather agency has multiple rural observation stations in Andalusia that hourly collect the environmental parameters of the site where they are located. The ambient temperature was needed to subsequently validate the satellite data, as indicated in the methodology section. So as to minimize the impact of the rural environment on calculation of the SUHI with Sentinel-3 images, the ones located in rural areas-surrounded by farmland and with few impervious surfaces - were selected for each city studied. This selection criterion has given statistically significant impacts in similar investigations (Wang et al. 2017; Jiang et al. 2019).

The rural stations of reference were selected taking into account the following considerations (Wang et al. 2017): (1) The \% of impervious surfaces around the station is roughly $10 \%$ and the proportion of farmland must be greater than $65 \%$; (2) the difference in surface elevation between the station and the city would be approximately $30 \mathrm{~m}$; (3) rural stations had to be outside the main urban areas; (4) An approximate area of $1000 \times$ $1000 \mathrm{~m}^{2}$ of equal coverage should surround the station. Given these prerequisites, a rural meteorological station was chosen for each city, its characteristics and location shown in Table 3.

Heat waves in Spain are often associated with strong anticyclonic conditions and large-scale subsidence with warm advection from North Africa in the lower atmosphere (Xoplaki et al. 2003). For the days and hours selected in this research, and from each rural meteorological station, the following data were obtained: ambient temperature, solar radiation, wind speed and direction. 
Table 3 Characteristics of rural meteorological stations in inland cities

\begin{tabular}{|c|c|c|c|c|c|c|c|c|}
\hline \multirow{2}{*}{$\begin{array}{l}\text { Geographic } \\
\text { information }\end{array}$} & \multicolumn{4}{|l|}{ Inland cities } & \multicolumn{4}{|l|}{ Coastal cities } \\
\hline & Sevilla & Cordoba & Jaen & Granada & Huelva & Cadiz & Malaga & Almeria \\
\hline $\begin{array}{l}\text { Name of } \\
\text { the rural } \\
\text { temperature } \\
\text { station }\end{array}$ & $\begin{array}{l}\text { Sevilla Air- } \\
\text { port }\end{array}$ & $\begin{array}{c}\text { Cordoba } \\
\text { Airport }\end{array}$ & Jaen City & $\begin{array}{l}\text { Granada } \\
\text { Airport }\end{array}$ & Huelva City & $\begin{array}{l}\text { Rota Naval } \\
\text { base }\end{array}$ & $\begin{array}{l}\text { Malaga Air- } \\
\text { port }\end{array}$ & $\begin{array}{l}\text { Almeria } \\
\text { Airport }\end{array}$ \\
\hline $\begin{array}{l}\text { Distance from } \\
\text { the station } \\
\text { to the city } \\
\text { center }(\mathrm{Km})\end{array}$ & 8.2 & 10.8 & 3 & 16 & 4 & 8.5 & 7 & 12 \\
\hline $\begin{array}{l}\text { Impervious } \\
\text { surface } \\
\text { nearby }(\%)\end{array}$ & 16 & 12 & 15 & 10 & 23 & 20 & 15 & 3 \\
\hline $\begin{array}{r}\text { Altitude } \\
\text { (masl) }\end{array}$ & 34 & 90 & 580 & 567 & 19 & 2 & 5 & 21 \\
\hline UTM & $\begin{array}{c}37.250 \mathrm{~N},- \\
5.524 \mathrm{~W}\end{array}$ & $\begin{array}{c}37.505 \mathrm{~N},- \\
4.504 \mathrm{~W}\end{array}$ & $\begin{array}{c}37.463 \mathrm{~N},- \\
3.483 \mathrm{~W}\end{array}$ & $\begin{array}{c}37.112 \mathrm{~N},- \\
3.472 \mathrm{~W}\end{array}$ & $\begin{array}{c}37.164 \mathrm{~N},- \\
6.544 \mathrm{~W}\end{array}$ & $\begin{array}{c}36.300 \mathrm{~N},- \\
6.195 \mathrm{~W}\end{array}$ & $\begin{array}{c}36.395 \mathrm{~N},- \\
4.285 \mathrm{~W}\end{array}$ & $\begin{array}{c}36.50 \mathrm{~N},- \\
2.212 \mathrm{~W}\end{array}$ \\
\hline
\end{tabular}

Source: State Meteorological Agency (AEMET)

Previous research (van Hove et al. 2015; Gaur et al. 2018; Jiang et al. 2019) indicates that solar radiation and wind speed and direction are elements that condition the intensity of SUHI in cities. The high pressures associated with heat waves decrease wind speed and cloud cover, which causes the earth's surface to receive more solar radiation. An increase in solar radiation produced by high pressure and low cloud cover increases environmental temperatures. Such circumstances reduce cooling and amplify the SUHI phenomenon (Oke 1987; Ackerman and Knox 2012; Li and Bou-Zeid 2013). Accordingly, certain studies (De Boeck et al. 2010; Wang et al. 2017; Jiang et al. 2019) report that during heat wave periods, solar radiation may be 2.5 times higher than under normal conditions, a fact related to SUHI amplification in many cities.

\subsection{Surface Urban Heat Island estimation}

In the literature, UHI and SUHI are defined in terms of different temperatures measured within an urban area and in rural areas surrounding the city, taken at the same time (Oke 1987). UHI refers to ambient temperatures and SUHI to terrestrial surface temperatures. Therefore, the SUHI can be determined according to Eq. 2:

$\mathrm{SUHI}=\mathrm{LST}_{\text {urban }}-\mathrm{LST}_{\text {rural }}$.

Having exported the LST images of Sentinel day and night to QGIS software, version 3.10.5, and with the help of the raster calculator command, the SUHI of the city was determined by means of Eq. 2 .

\subsection{Analytical Strategy}

Introducing the Data Panel method of statistical analysis in the model entailed two phases (Chen et al. 2011). Firstly, by means of the Hausman proof, the effects of analysis were determined to be either fixed or random. Then the model was assessed in view of the results obtained in Wooldridge and Wald Tests. There are three options for calculation: Method of Ordinary Squares (MOS), Generalized Least Squares (GLS) and the Method of Intragroup Estimators (MIE) (Labra 2014).

The first of the three, while widely used for years, does not enable the effects of every individual to be analyzed over the course of time, which can give rise to biased estimators.

The second is considered to be a more efficient extension of the first. It is assumed that individual effects are not reflected in the explanatory variables of the model; instead, they contribute to the error term, following the expression:

$Y_{i t}=\beta X_{i t}+\left(\alpha_{i}+\mu_{i t}\right)$,

where $\alpha_{i}$ represents the individual effects, $\mu_{i t}$ is the error of the model, $X$ would represent explanatory variables, $i=$ individual and $t=$ time.

The third method cited above assumes that individual effects are in line with the explanatory variables, so that the individual effect is separated after error, under the following calculation:

$Y_{i t}=\alpha_{i}+\beta X_{i t}+\mu_{i t}$ 
where, again, $\alpha_{i}$ are the individual effects, $\mu_{i t}$ is the error of the model, $X$ are explanatory variables, $i=$ individual and $t=$ time.

\section{Results}

\subsection{Land Surface Temperature by Sentinel day and night versus Rural Weather Stations}

Overall, the Sentinel day and night products present higher mean values than those obtained from the AEMET rural meteorological stations for the study periods in 2019 and 2020. The two temperatures are different but correlated, meaning they will serve later to validate the LST data obtained by satellite. Specifically, in the morning the highest mean LST values are obtained using the official product Sentinel day $\left(39.46^{\circ} \mathrm{C}\right)$, while the mean environmental temperature of the rural station was lower $\left(35.87^{\circ} \mathrm{C}\right)$. At night, the highest mean LST values are obtained with the official Sentinel product $\left(24.05{ }^{\circ} \mathrm{C}\right)$, and the mean environmental temperature of rural stations was again lower $\left(21.10^{\circ} \mathrm{C}\right)$. The mean differences obtained between the LSTs with satellite images and the rural stations amounted to $3.59{ }^{\circ} \mathrm{C}$ for Sentinel Day, and $2.95{ }^{\circ} \mathrm{C}$ for Sentinel night. Findings of increased LST with Sentinel-3 images are reproduced for both inland cities and coastal cities: the former show LST differences of $3.70{ }^{\circ} \mathrm{C}$ with Sentinel day and $3.10^{\circ} \mathrm{C}$ with Sentinel night, while coastal cities show LST differences of $3.48^{\circ} \mathrm{C}$ with Sentinel day and $2.84{ }^{\circ} \mathrm{C}$ with Sentinel night.

\subsection{LST Amplified Under Heat Waves}

The statistics of the daytime and nighttime LST obtained by means of the Sentinel day and night products for the inland and coastal Andalusian cities during the period under study are shown in Fig. 3. As can be seen, the daytime LSTs of the inland cities are higher than the LSTs of the coastal cities, whether under normal environmental conditions or in periods of heat wave. The nighttime LSTs of inland cities are seen to be lower than those of coastal cities, both under normal environmental conditions and during heat waves.

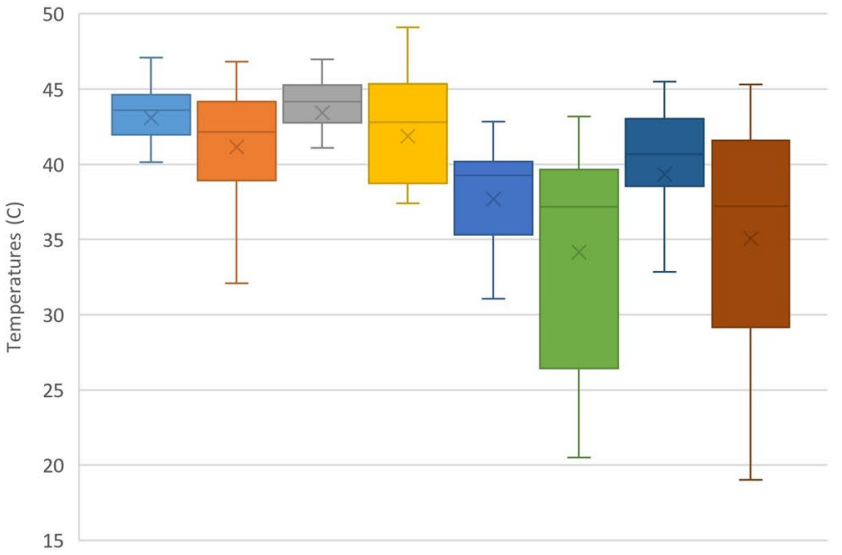

(a)

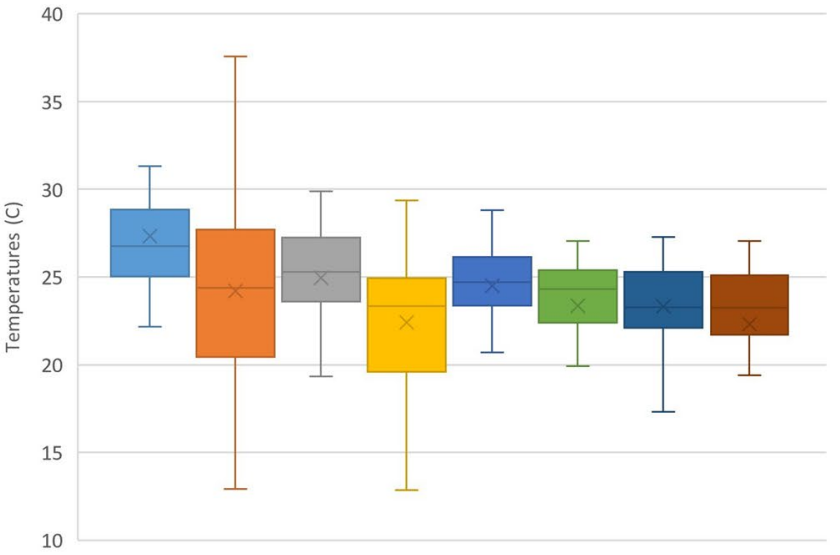

(b)

$\square$ Inland cities. T. urban, normal conditions.

$\square$ Coastal cities. T. urban, heat waves.

- Coastal cities. T. rural, normal conditions. $\square$ Inland cities. T. rural, heat waves,

$\square$ Coastal cities. T. urban, normal conditions.

Coastasl cities. T. rural, heat waves.

during the period under study

Fig. 3 LST Sentinel Day (a) and night (b) by city type and during the period under study

Table 4 LST results with Sentinel day and Sentinel night urban and rural areas

\begin{tabular}{|c|c|c|c|c|c|c|c|c|}
\hline \multirow[b]{2}{*}{ Zones } & \multicolumn{2}{|c|}{$\begin{array}{l}\text { Daytime normal } \\
\text { conditions }\end{array}$} & \multicolumn{2}{|c|}{ Daytime heat waves } & \multicolumn{2}{|c|}{$\begin{array}{l}\text { Nighttime normal } \\
\text { conditions }\end{array}$} & \multicolumn{2}{|c|}{$\begin{array}{l}\text { Nighttime heat } \\
\text { waves }\end{array}$} \\
\hline & Urban & Rural & Urban & Rural & Urban & Rural & Urban & Rural \\
\hline Inland cities & 41.13 & 41.87 & 43.06 & 43.42 & 23.37 & 22.31 & 24.19 & 22.40 \\
\hline Differences & 0.74 & & 0.36 & & 1.06 & & 1.79 & \\
\hline Coastal cities & 34.15 & 35.05 & 37.68 & 39.31 & 24.50 & 23.33 & 27.34 & 24.94 \\
\hline Differences & 0.90 & & 1.63 & & 1.17 & & 2.40 & \\
\hline
\end{tabular}

Temperatures: ${ }^{\circ} \mathrm{C}$ 
As can be seen in Table 4, during the mornings the LST values of urban areas are lower than the values of rural areas. Numerous academic studies (Saaroni et al. 2018; Wu et al. 2019; Yang et al. 2020a) indicate that the reasons for the higher LST in rural areas is motivated by the higher long wave radiation received by rural areas compared to urban ones, owing to the shade generated by buildings and trees and the cooling rates produced in urban green areas. The increases in diurnal LST in inland cities under heat wave conditions with respect to the same areas in normal conditions were $1.93{ }^{\circ} \mathrm{C}$ and $1.55{ }^{\circ} \mathrm{C}$ for urban and rural areas, respectively. In contrast, the nocturnal temperature differences respectively amounted to $3.15{ }^{\circ} \mathrm{C}$ and $2.54{ }^{\circ} \mathrm{C}$. The diurnal LST increase in coastal cities in heat wave conditions with respect to the same areas in normal conditions was $3.53{ }^{\circ} \mathrm{C}$ for urban and $4.26{ }^{\circ} \mathrm{C}$ for rural areas. The nocturnal increases gave values of $1.13{ }^{\circ} \mathrm{C}$ and $1.02{ }^{\circ} \mathrm{C}$, respectively.

In view of the above results, it can be said that periods of heat wave entail increases in the day and night LSTs for both urban and rural areas, in the coastal as well as the inland cities of Andalusia. Still, the increase is greater during the morning in the coastal cities, and in the afternoon in the inland cities (Table 4). During the morning, the coastal cities present average values that are $3.90{ }^{\circ} \mathrm{C}$ higher when compared to the periods of normal environmental conditions; the increase in LST produced in the inland cities is, in contrast, only $1.74{ }^{\circ} \mathrm{C}$. Contrariwise, at night, the coastal cities present mean values $1.08{ }^{\circ} \mathrm{C}$ higher than the values for periods of normal environmental conditions, as opposed to the increase in LST produced in the inland cities of $2.85^{\circ} \mathrm{C}$.

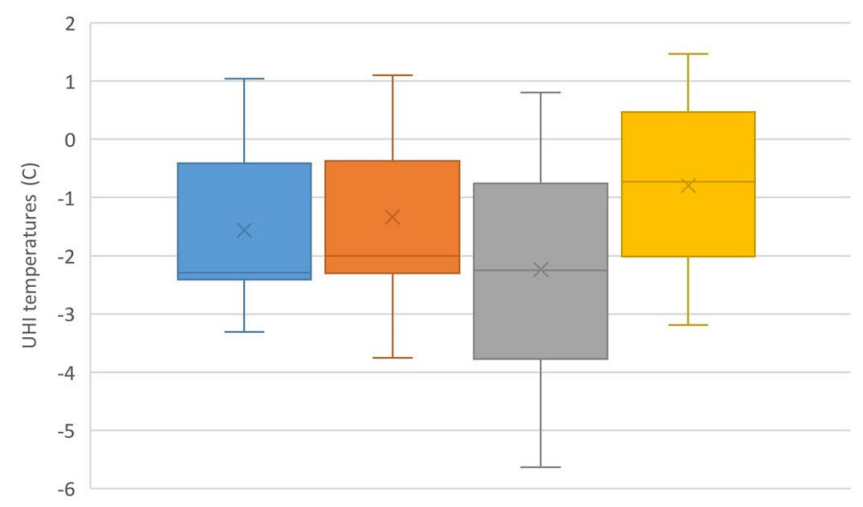

(a)

$\square$ Inland cities UHI, heat waves.
$\square$ Coastal cities UHI, heat waves.

\subsection{SUHI Amplified Under Heat Waves}

The statistics of the diurnal SUHI obtained with day and night Sentinel products for the inland and coastal cities during the study period are shown in Fig. 4.

As Table 5 shows, the cities of Andalusia present negative mean values for the diurnal SUHI that intensify in heat wave conditions, most notably in coastal cities. Similarly, the night SUHIs present positive mean values, intensified under heat wave conditions. However, their intensification is greater in inland cities than in coastal cities. The negative values indicate that during the morning, temperatures in rural areas are higher than temperatures in urban areas, producing the phenomenon known as urban cooling island (Saaroni et al. 2018; Wu et al. 2019; Yang et al. 2019). In the early morning hours, solar radiation is greater in rural areas because in the city, shade is generated by buildings, trees, and the heterogeneous system of impermeable walls with great thermal absorption and heat capacity. The sources of shade in the city prevent long wave solar radiation from heating the waterproof walls of urban areas and giving off

Table 5 SUHI results with Sentinel day and night, urban and rural areas

\begin{tabular}{lllll}
\hline Cities & $\begin{array}{l}\text { Daytime } \\
\text { normal con- } \\
\text { ditions }\end{array}$ & $\begin{array}{l}\text { Daytime } \\
\text { heat } \\
\text { waves }\end{array}$ & $\begin{array}{l}\text { Nighttime } \\
\text { normal condi- } \\
\text { tions }\end{array}$ & $\begin{array}{l}\text { Nighttime } \\
\text { heat waves }\end{array}$ \\
\hline Inland cities & -1.33 & -1.56 & 0.95 & 1.47 \\
Differences & 0.23 & & 0.52 & \\
Coastal cities & -0.80 & -2.24 & 1.06 & 1.11 \\
Differences & 1.44 & & 0.05 & \\
\hline
\end{tabular}

Temperatures: ${ }^{\circ} \mathrm{C}$

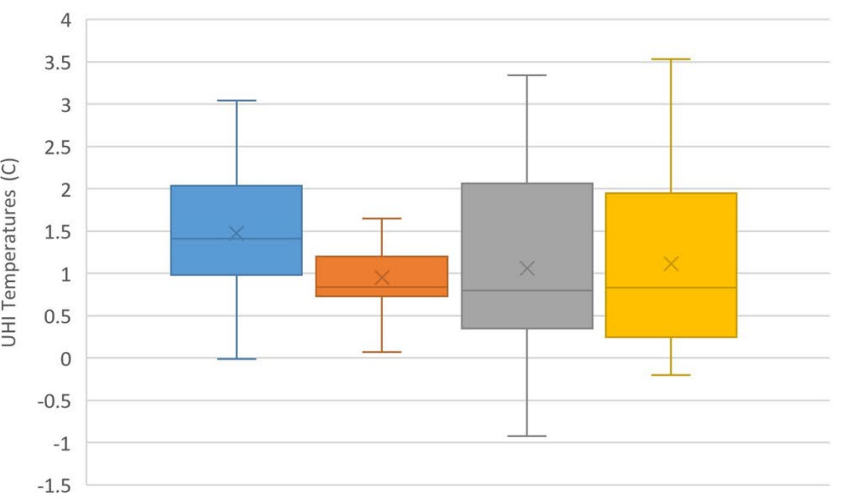

(b)

Inland cities UHI, normal conditions.

Coastal cities UHI, normal conditions.

Fig. 4 SUHI Sentinel Day (a) and night (b) by city type during the period under study 
high doses of heat, altering the LST of the area (Li and Meng 2018; Lemus et al. 2020; Logan et al. 2020; Yang et al. 2020b). The areas where the rural stations are located are farmlands with less than $10 \%$ of impervious surfaces and a mean NDVI that ranges between 0.2 and 0.5 .

Figures 5 and 6 illustrate the diurnal and nocturnal SUHI values under heat wave conditions (blue line) and under normal environmental conditions (brown line). In general, the blue lines are found above the brown lines, indicating that the temperatures in heat wave periods are higher than the values under normal conditions. These increases occur in both inland and coastal cities. Yet the increases are greater during the day in coastal cities, and at night in inland cities.

Figure 7 shows the mean SUHI during the period under study obtained with Sentinel day for coastal cities under normal environmental conditions and under heat wave conditions. The intensity and extension of the SUHI are seen to be greater in the images obtained during the heat wave.

Figure 8 shows the mean SUHI during the period under study obtained with Sentinel night for inland cities under both normal environmental conditions and heat wave conditions. Both the intensity and the extension of the SUHI are greater in the images obtained during the heat wave.

\subsection{Statistical Analysis}

\subsubsection{Satellite Temperature Validation}

To validate the satellite data obtained, it is important to obtain the linear adjustment coefficients $R^{2}$, correlation coefficient (CC), standard deviation (SD), the mean bias error (MBE) and the root mean square error (RMSE), each indicated in Table 6. The results of $R^{2}$ are considered adequate since they present values above 0.94 . This circumstance indicates good concordance between the values analyzed, being above $94 \%$ and considered statistically significant.

Because these values denote a good agreement between the environmental temperature values and the LST obtained from the satellite, they lend validity to the results obtained.
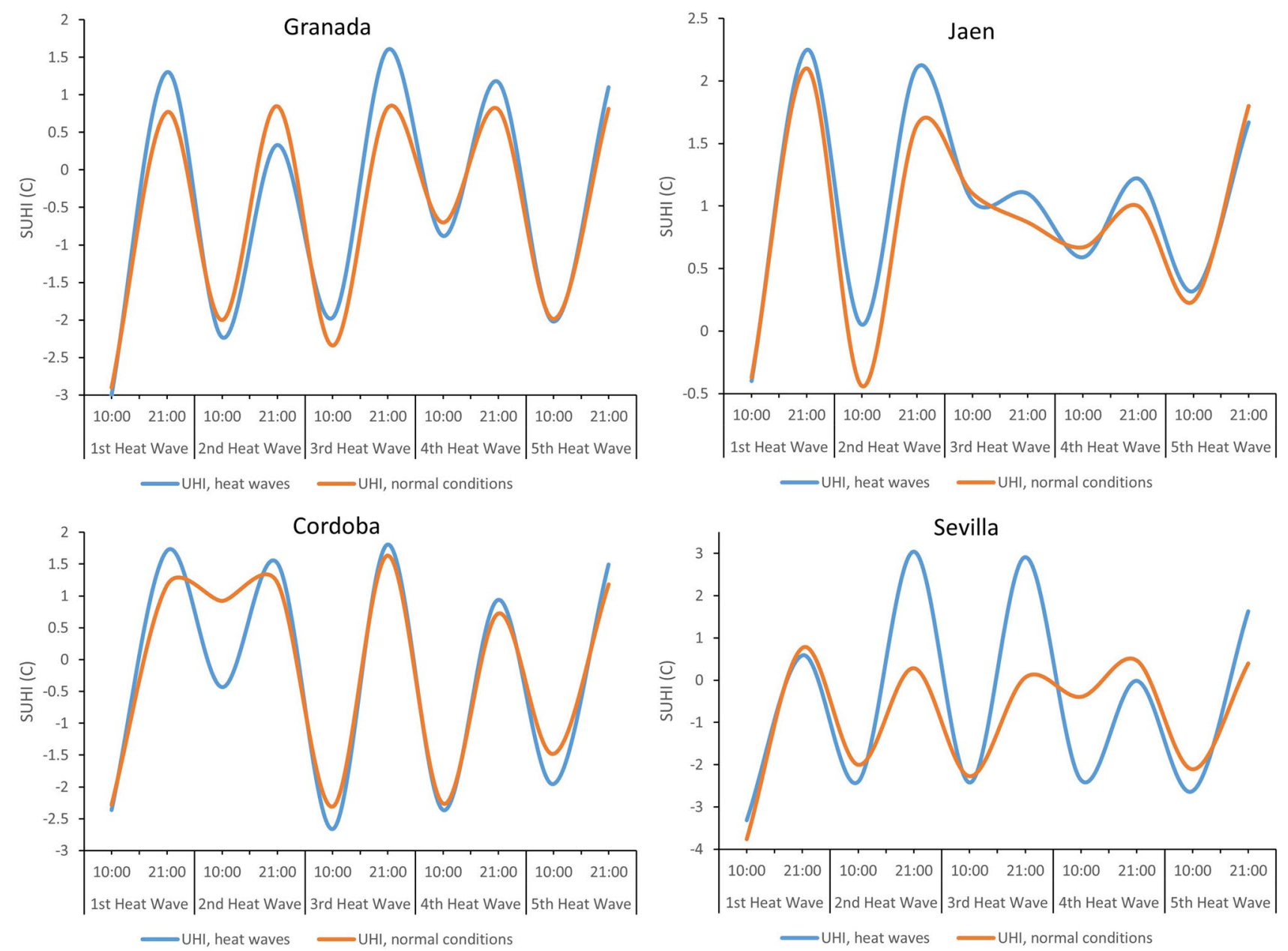

Fig. 5 Average SUHI in inland cities under normal conditions and under heat wave, according to Sentinel day and night 

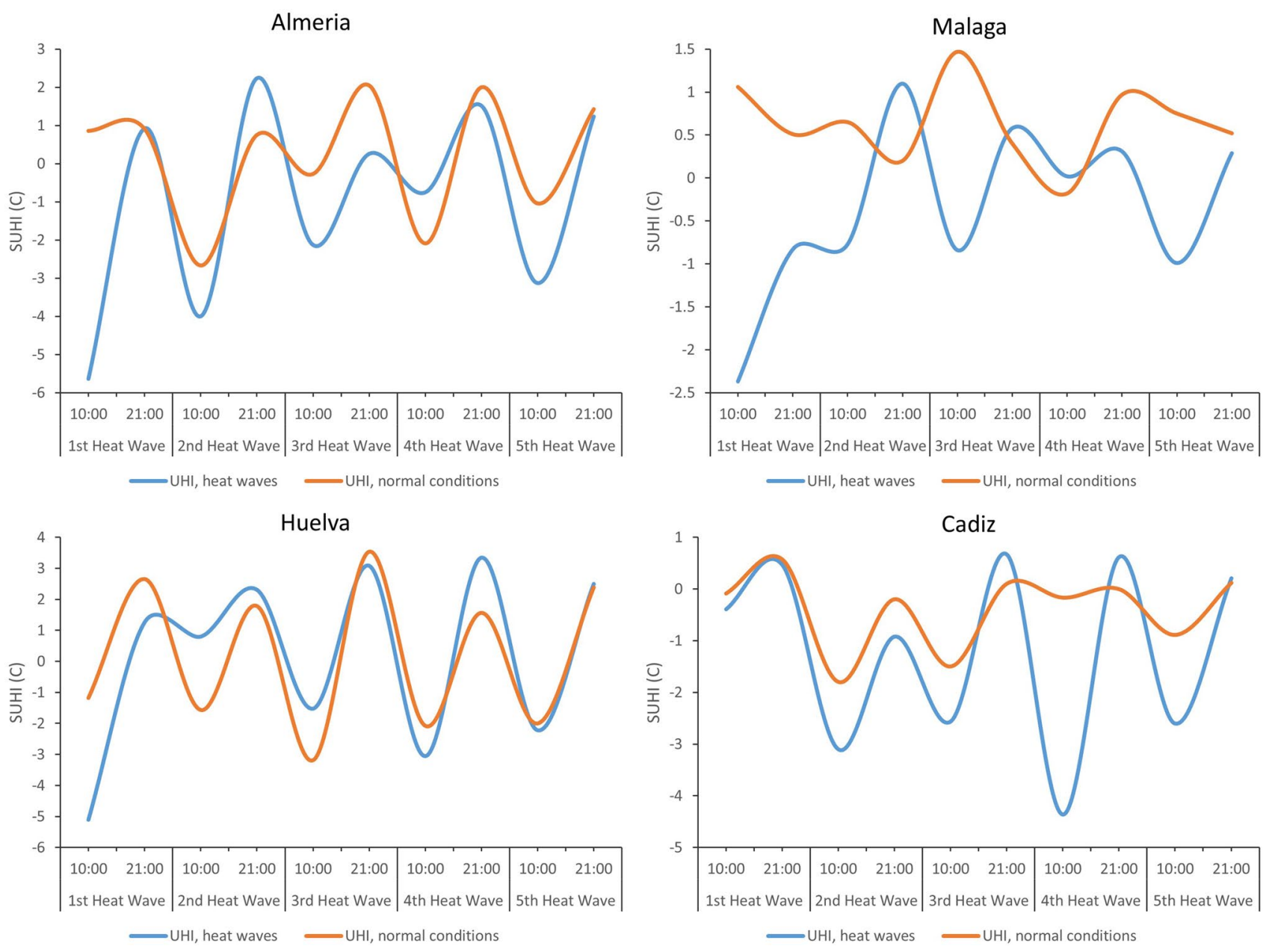

Fig. 6 Average SUHI in coastal cities under normal conditions and under heat wave, according to Sentinel day and night

Next, the statistical analysis of the variables that could influence the SUHI obtained with Sentinel day and night was carried out using the Data Panel method. The variables were: solar radiation, wind speed, and wind direction. It was first necessary to determine whether calculation should be carried out using fixed or random effects. The Hausman test was implemented to this end, its results marking the need to use the panel of robust random effects for the data obtained in the first and in the second phase of analysis. To develop the Data Panel, the Generalized Least Method (GLM) was used, with Eq. 3.

\subsubsection{Interaction between SUHI and LST}

The results of the statistical analysis of the LST and SUHI data obtained by Sentinel day and night in the study periods are given in Table 7.

The results of the statistical analysis of the SUHI data obtained through Sentinel day and night images point to a statistically significant relationship of $95 \%$ with the independent variable LST. The values obtained for $R^{2}$ and the $F$ statistic of the SUHI data are shown in Table 8 . The data show good agreement between the dependent and independent variables according to the method used, with a level of adjustment lower than $90 \%$ significance, as Prob $>\mathrm{chi}^{2}>0.000$.

\subsection{Solar Radiation Contributions to the SUHI}

The AEMET has certified points for the measurement of direct and diffuse solar radiation at rural meteorological stations. Direct solar radiation is obtained by means of a Kipp-Zonen Pyrheliometer, while for diffuse solar radiation a Kipp-Zonen Pyranometer is used, periodically calibrated against international standards. The solar radiation of the rural stations of the AEMET were analyzed for the purposes of our study to grasp its influence on the variability of SUHI intensity in the cities of Andalusia. The data obtained reflect that total daily radiation is some 1.2 times higher in heat wave periods than under normal 
Fig. 7 Mean SUHI during

period under study for coastal

cities in a normal environmental

conditions, and $\mathbf{b}$ heat wave

conditions
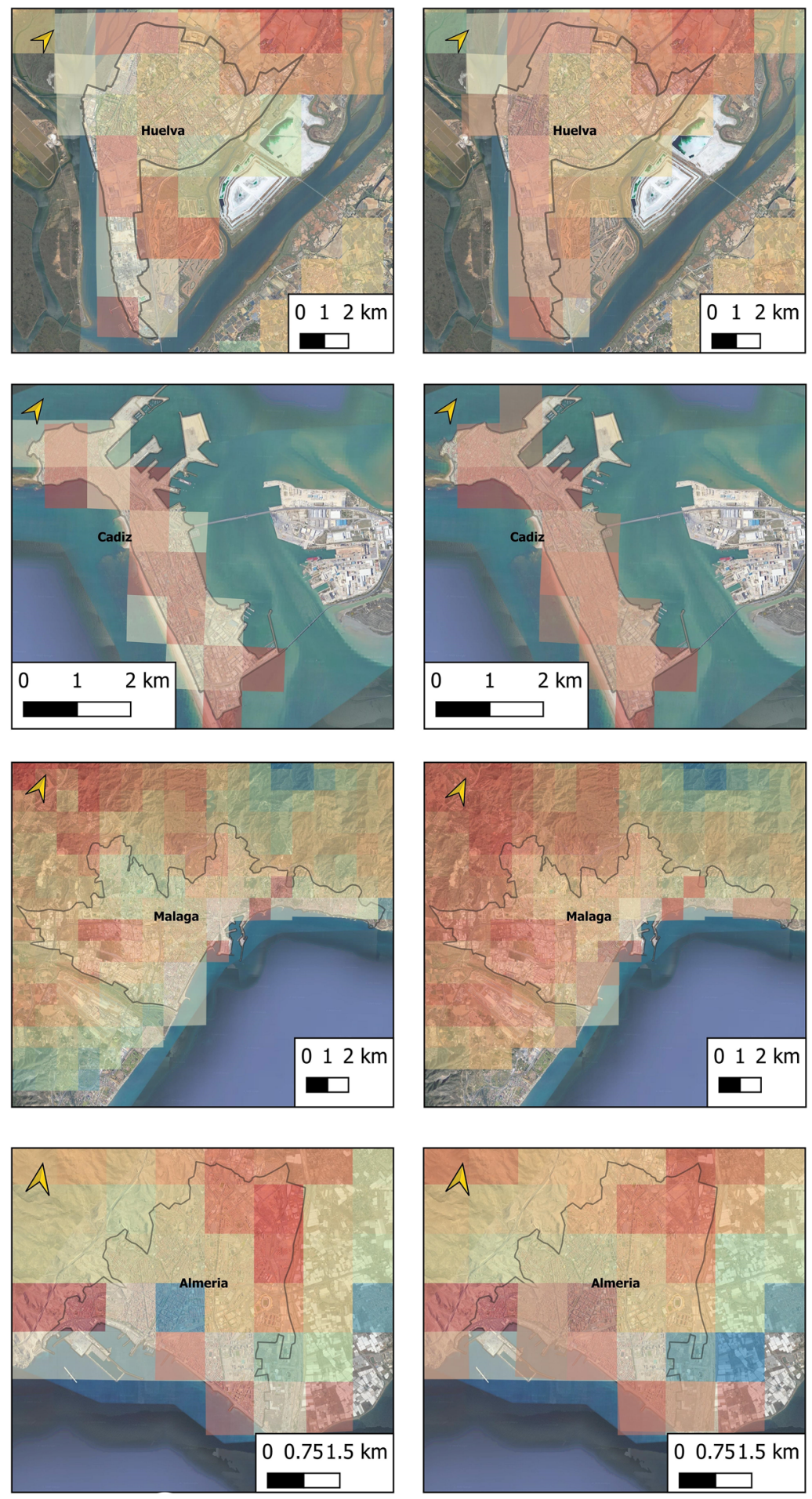

(a)

(b)

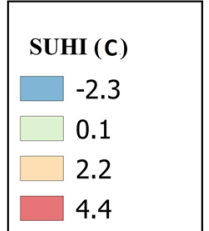


Fig. 8 Mean SUHI during period under study for inland cities in a normal environmental conditions and $\mathbf{b}$ heat wave conditions
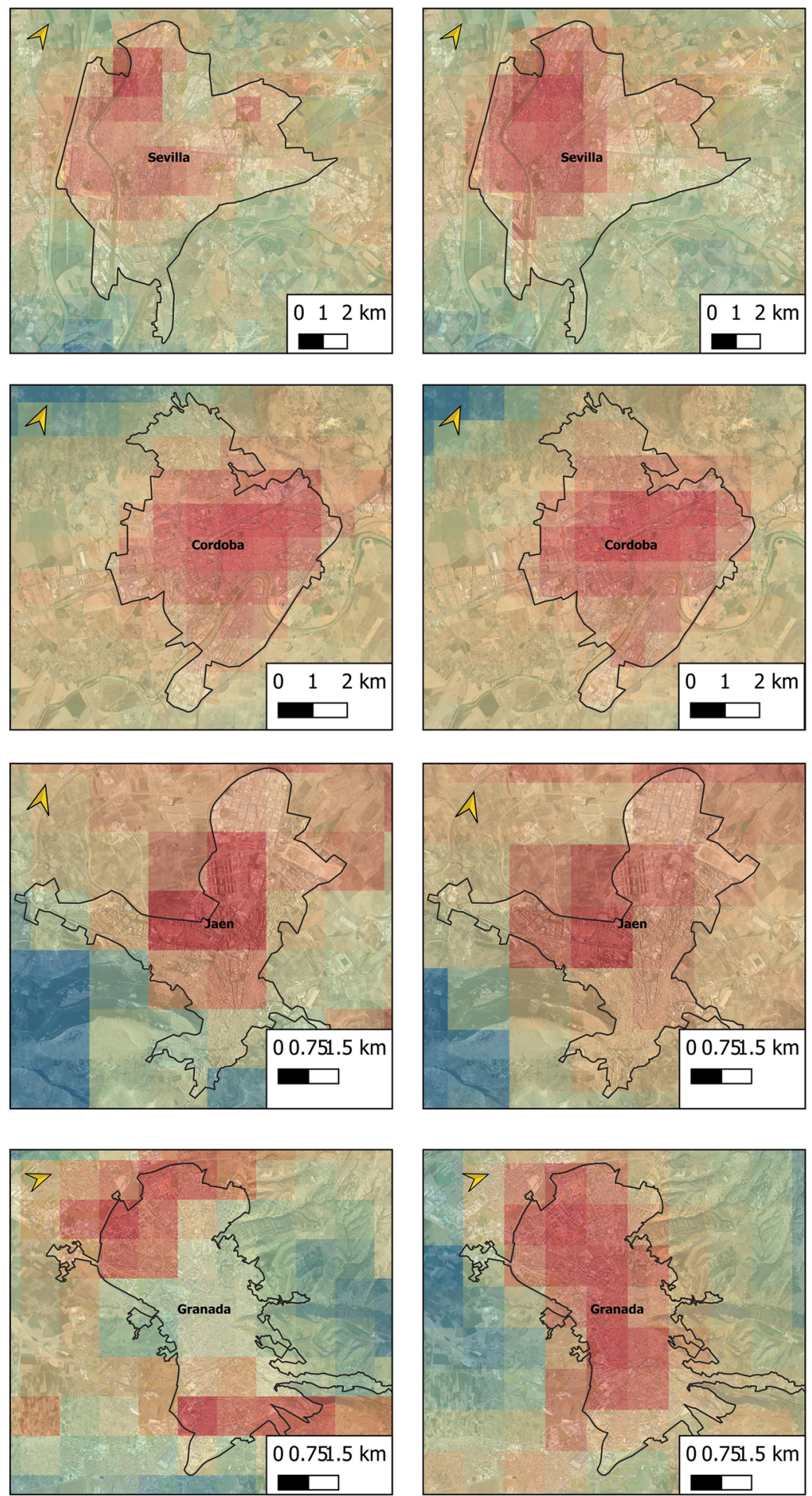

(a)

(b)

\begin{tabular}{|c|}
\hline SUHI (C) \\
-2.8 \\
-1.3 \\
0.2 \\
1.7 \\
\hline
\end{tabular}


Table 6 Data panel results for Sentinel: relationships between SUHI and LST

\begin{tabular}{llllll}
\hline Satellite & CC & $R^{2}$ & SD & MBE & RMSE \\
\hline Sentinel day & 0.9970 & 0.95 & 8.57 & -4.10 & 2.92 \\
Sentinel night & 0.9902 & 0.97 & 6.36 & -3.85 & 3.18
\end{tabular}

$C C$ correlation coefficient, $R$ : linear adjustment, $S D$ standard deviation, $M B E$ mean bias error, $R M S E$ root mean square error

conditions. This ratio is reduced to 1.05 times in the LST and SUHI data collection chart based on Sentinel day, and up to 1.08 times higher in charts corresponding to Sentinel night. The atmospheric pressure during the periods of heat wave was 1.3 times higher than under normal conditions. These results suggest that Andalusia tends to have higher atmospheric pressures associated with less cloud cover during heat wave days, which allows more solar radiation to reach the earth's surface, as brought out in other studies (De Boeck et al. 2010; Li et al. 2015; Jiang et al. 2019).
The results of the statistical analysis of the SUHI data obtained by Sentinel day and night in periods of normal conditions and in heat waves with regard to solar radiation are indicated in Table 9.

The results of the statistical analysis of the SUHI data obtained through Sentinel day images point to a statistically significant relationship above $99 \%$ with the independent variable solar radiation, both under normal atmospheric conditions and in heat wave periods. The results of the statistical analysis of the SUHI data obtained through Sentinel night images indicate a statistically significant relationship of $99 \%$ with the independent variable solar radiation during periods of normal atmospheric conditions, and above $99 \%$ during heat waves. The cities are located in latitudes where the sunset during the summer period is after the time of the Sentinel night.

The values obtained for $R^{2}$ and the $F$ statistic of the SUHI data for Sentinel day and night are shown in Table 10. The data are seen to show good agreement between the dependent and independent variables according to the method
Table 7 Data panel results for Sentinel: relationships between SUHI and LST

Table $8 R^{2}$ and F SUHI statistical analysis for Sentinel: relationships with LST

Table 9 Data panel results for Sentinel: relationships with solar radiation

Table $10 R^{2}$ and F SUHI statistical analysis for Sentinel: relationships with solar radiation

\begin{tabular}{|c|c|c|c|c|c|c|}
\hline \multirow{2}{*}{$\begin{array}{l}\text { Satellite } \\
\text { Variables }\end{array}$} & \multicolumn{3}{|c|}{ Sentinel day } & \multicolumn{3}{|c|}{ Sentinel night } \\
\hline & $\beta$ & $\rho$ & SD & $\beta$ & $\rho$ & SD \\
\hline LST & -0.0904 & 0.031 & 0.0419 & -0.0954 & 0.035 & 0.4538 \\
\hline
\end{tabular}

$\beta$ Constant, $S D$ standard deviation, $\rho P$ value

\begin{tabular}{|c|c|c|c|c|c|c|}
\hline \multirow{2}{*}{$\begin{array}{l}\text { Satellite } \\
\text { Variables }\end{array}$} & \multicolumn{3}{|c|}{ Sentinel day } & \multicolumn{3}{|c|}{ Sentinel night } \\
\hline & $\overline{R^{2}}$ & $F$ & Prob $>\mathrm{chi}^{2}$ & $\overline{R^{2}}$ & $F$ & Prob $>\mathrm{chi}^{2}$ \\
\hline LST & 0.55 & 4.66 & 0.0031 & 0.69 & 4.42 & 0.0035 \\
\hline
\end{tabular}

$R 2$ linear adjustment, $F \mathrm{~F}$ statistic

\begin{tabular}{|c|c|c|c|c|c|c|}
\hline \multirow[t]{2}{*}{ Satellite } & \multicolumn{3}{|c|}{ Normal conditions } & \multicolumn{3}{|c|}{ Heat waves } \\
\hline & $\beta$ & $\rho$ & SD & $\beta$ & $\rho$ & SD \\
\hline Sentinel day & 0.0739 & $<0.001$ & 0.01844 & 0.0834 & $<0.001$ & 0.00234 \\
\hline Sentinel night & 0.0062 & 0.002 & 0.00203 & 0.0075 & $<0.001$ & 0.00058 \\
\hline
\end{tabular}

$\beta$ Constant, $S D$ standard deviation, $\rho P$ value

\begin{tabular}{llllllll}
\hline Satellite & \multicolumn{2}{l}{ Sentinel day } & & \multicolumn{2}{l}{ Sentinel night } \\
\cline { 2 - 4 } \cline { 6 - 8 } & $R^{2}$ & $F$ & Prob $>\mathrm{chi}^{2}$ & & $R^{2}$ & $F$ & Prob $>\mathrm{chi}^{2}$ \\
\hline Normal conditions & 0.71 & 16.06 & 0.0004 & & 0.72 & 9.42 & 0.0009 \\
Heat waves & 0.72 & 18.50 & 0.0001 & & 0.75 & 166.39 & 0.0000 \\
\hline
\end{tabular}

$R 2$ Linear adjustment, $F$ F statistic 
used, with an adjustment level of $99 \%$ significance, since Prob $>\mathrm{chi}^{2}<0.000$. The $R^{2}$ and $F$ values are slightly higher for heat wave conditions than for normal environmental conditions, which denotes that the relationship between SUHI and solar radiation is stronger during heat waves.

\subsubsection{Wind Speed and Direction Contributions to the SUHI}

The wind speed and wind direction data from the rural stations of the AEMET were analyzed to discern their influence on the variable intensity of the SUHI in the cities of Andalusia. The direction under normal conditions is from sea to inland (northward), while during heat wave environmental conditions, the predominant wind direction is from land to sea (southward). This means that during the day, in heat wave conditions, the cool breeze from the sea-which is usual in normal environmental conditions-does not reach cities, so that the LST and SUHI increase. The change in wind direction therefore has a strong impact on the ambient temperature.

Our data reflect a mean daytime wind speed during data collection using Sentinel day was approximately 1.16 times higher during periods of normal conditions than during heat waves. This proportion increases slightly, to 1.18 times, using Sentinel night.

Tables 11 and 12 offer the results of statistical analysis of the SUHI data obtained with Sentinel day and night in normal conditions versus periods of heat wave in terms of wind speed and direction. The analysis of SUHI data obtained with Sentinel day and night images gives no statistically significant relationship among the variables analyzed for periods of normal conditions. In contrast, with Sentinel day and under heat wave conditions there is a statistically significant relationship above $99 \%$ with the variable wind direction, slightly reduced to just $99 \%$ by Sentinel night.

The values obtained for $R^{2}$ and the $F$ statistic of the SUHI data from Sentinel 3A and 3B are shown in Table 13.

The data gathered in periods of normal conditions do not show good agreement between the dependent variable and the independent variables according to the method used, with a level of adjustment lower than $90 \%$ significance, as Prob $>\mathrm{chi}^{2}>0.000$. On the contrary, for periods of heat wave, method used indicates good agreement between the dependent variable and the independent variables, with an adjustment level greater than $99 \%$ significance, Prob $>\mathrm{chi}^{2}<0.000$. The $R^{2}$ and $F$ values are slightly higher in heat wave conditions than in normal environmental conditions, which denotes that the relationship between SUHI and wind speed and direction is stronger during heat wave periods.

\subsubsection{Increase in the Surface Affected by SUHI During Heat Wave Period}

During heat waves, there is not only an increase in the LST and an intensification of the SUHI of the analyzed cities, but larger urban areas are reportedly affected by the SUHI as well. The average increase in these terms during the heat
Table 11 Data panel results Sentinel day: relationship with wind speed and direction

Table 12 Data panel results Sentinel night: relationship with wind speed and direction

Table $13 \mathrm{R}^{2}$ and F SUHI for Sentinel: relationship with wind speed and direction

\begin{tabular}{lllllllll}
\hline Satellite & \multicolumn{5}{l}{ Sentinel day, normal conditions } & & \multicolumn{4}{l}{ Sentinel day, heat waves } \\
\cline { 2 - 3 } & $\beta$ & $\mathrm{p}$ & $\mathrm{SD}$ & & $\beta$ & $\mathrm{p}$ & $\mathrm{SD}$ \\
\hline Wind speed & 0.0381 & 0.636 & 0.08068 & & -0.0562 & 0.316 & 0.05614 \\
Wind direction & -0.0015 & 0.497 & 0.00231 & & -0.0053 & $<0.001$ & 0.00146 \\
\hline
\end{tabular}

$\beta$ Constant, $S D$ Standard deviation, $p P$ value $p$ value is indicated in italics

\begin{tabular}{llllllll}
\hline Satellite & \multicolumn{3}{l}{ Sentinel night, normal conditions } & & \multicolumn{4}{l}{ Sentinel night, heat waves } \\
\cline { 2 - 3 } & $\beta$ & $\mathrm{p}$ & $\mathrm{SD}$ & & $\beta$ & $\mathrm{p}$ & $\mathrm{SD}$ \\
\hline Wind speed & -0.0651 & 0.049 & 0.03315 & & -0.0234 & 0.936 & 0.2913 \\
Wind direction & 0.0028 & 0.244 & 0.00246 & & -0.0057 & 0.005 & 0.0021 \\
\hline
\end{tabular}

$\beta$ Constant, $S D$ standard deviation, $p P$ value

$p$ value is indicated in italics

\begin{tabular}{llllllll}
\hline Satellite & \multicolumn{3}{l}{ Sentinel day } & & \multicolumn{3}{l}{ Sentinel night } \\
\cline { 2 - 4 } \cline { 6 - 8 } & $R^{2}$ & $F$ & Prob $>\mathrm{chi}^{2}$ & & $R^{2}$ & $\mathrm{~F}$ & Prob $>\mathrm{chi}^{2}$ \\
\hline Normal conditions & 0.65 & 3.72 & 0.1555 & & 0.71 & 4.30 & 0.1167 \\
Heat waves & 0.69 & 13.44 & 0.0009 & & 0.75 & 8.90 & 0.0007 \\
\hline
\end{tabular}

$R^{2}$ Linear fitting coefficient, $F$ F statistic 
Fig. 9 Surface area increases under normal conditions and under heat waves, and increase in urban area by cities

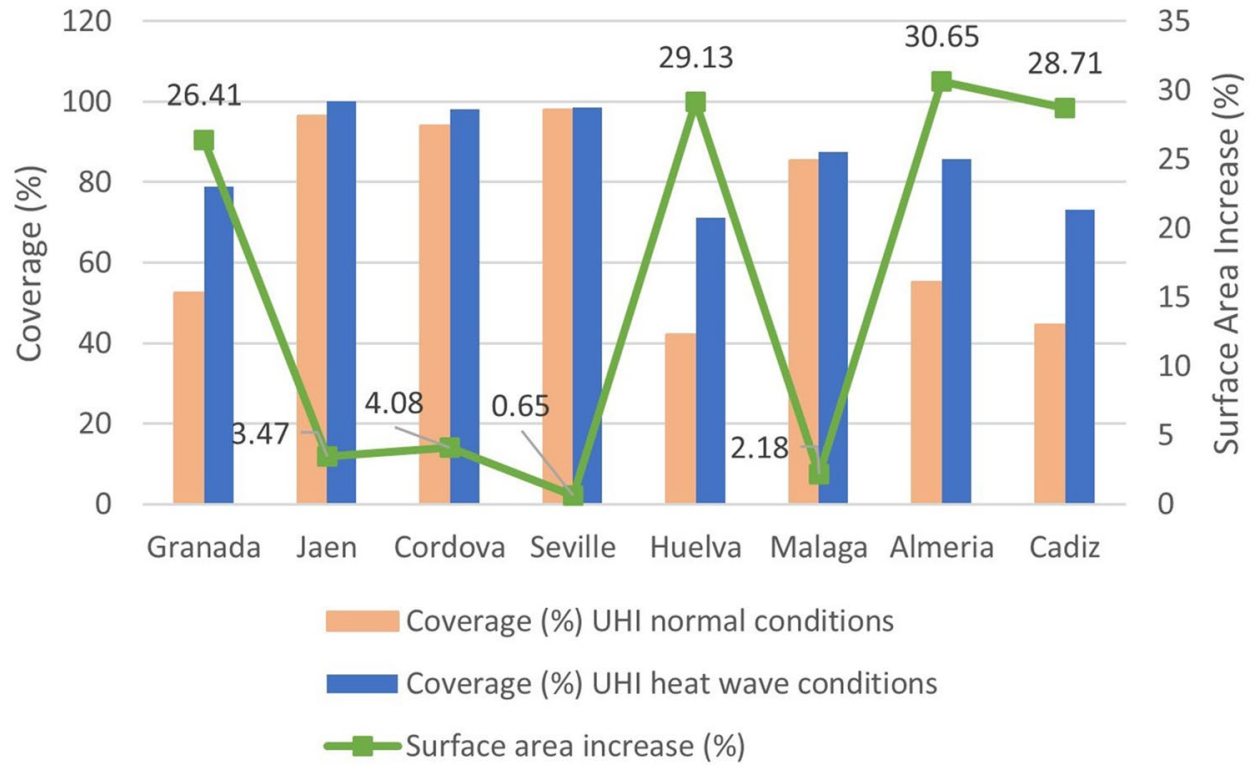

wave periods studied was $15.66 \%$ for the urban areas of the cities of Andalusia.

A substantially greater increase is observed in coastal cities $(22.67 \%)$ than in inland cities $(8.65 \%)$. Figure 9 shows the affected urban area under normal environmental conditions, under heat wave conditions, and the increase in the urban area of each city. It should be noted that, in general, inland cities have larger urban areas affected by SUHI under normal conditions $(85.23 \%)$ than coastal cities $(56.76 \%)$. This circumstance is possibly motivated by the direction of the wind, from the sea and towards the land (northward), which minimizes the LST in the latter cities. Under heat wave conditions, inland cities also present greater total urban areas affected (93.88\%) than coastal cities $(79.43 \%)$, although the highest growth of SUHI occurs in coastal cities. The change in wind direction (southward) can be considered the reason for this finding.

\section{Discussion}

The results presented here, for Sentinel day and night products used to obtain the LST and the SUHI in the cities of Andalusia, present adequate yields that are consistent with each other and similar to those provided by similar investigations (Li et al. 2011; Tan and Li 2015; Sobrino et al. 2016; Prikaziuk and van der Tol 2019; Yang et al. 2019, 2020b; Chiang and Ivan 2020; Hu et al. 2020; Venter et al. 2020).

The data obtained with Sentinel day, both for inland cities and coastal cities, give mean LSTs in rural areas that are higher than the mean LSTs in urban areas, both in periods of normal environmental conditions and in periods of heat wave. Unlike Sentinel day, Sentinel night data report that both inland cities and coastal cities have mean LSTs in rural areas that are lower than the mean LSTs of urban areas, whether under normal conditions or in heat waves. There are numerous academic studies that corroborate this situation between urban and rural temperatures in the early hours of the morning and at night, motivated by the solar radiation received (Zakšek et al. 2005; Keramitsoglou et al. 2011; Li et al. 2011; Feizizadeh and Blaschke 2013; Li and Bou-Zeid 2013; Mallick et al. 2013; Founda and Santamouris 2017; Tsou et al. 2017; Barbieri et al. 2018; Li and Meng 2018; Saaroni et al. 2018; Karakuş, 2019; Wu et al. 2019; Yang et al. 2019, 2020a, b; Lemus et al. 2020).

The mean values of SUHI obtained through Seninel day images for inland and coastal cities were negative. This finding, likewise evoked by other authors, would be determinant of an urban cooling island (Saaroni et al. 2018; Wu et al. 2019; Yang et al. 2020a). In turn, the mean SUHI data obtained by Sentinel night for inland and coastal cities were positive-indicative of an urban heat island, a phenomenon previously studied (Li et al. 2011; Shwarz et al. 2011; Lai et al. 2018; Luo and Lau 2018; Zhao et al. 2018; Tewari et al. 2019; Anjos et al. 2020; Huang et al. 2020; Santamouris, 2020). In light of our data, it can be said that during periods of heat waves there is an intensification of the SUHI obtained by Sentinel day and night, both in inland cities and in coastal cities. However, this intensification is greater with Sentinel day in coastal cities, and with Sentinel night in inland cities. Numerous academic studies corroborate the intensification of the SUHI at night (Gregor et al. 2007; Basara et al. 2010; House and Santamouris 2011; Founda et al. 2015; Jiang et al. 2019;) and during the day (House and Santamouris 2011; Founda and Santamouris 2017; Ao et al. 2019; Jiang 
et al. 2019; Qiu et al. 2020; Santamouris 2020) in periods of heat wave.

The data on total daily solar radiation obtained attest to a 1.2-times increase in periods of heat wave with respect to normal conditions, corroborated by statistical analysis. A number of academic studies confirm this association between solar radiation and SUHI (De Boeck et al. 2010; Li et al. 2015; Li and Bou-Zeid 2013; Jiang et al. 2019), serving to validate the data obtained in our investigation.

The wind speed and direction data gathered in our study denote important changes in the cities of Andalusia between periods of normal environmental conditions and periods of heat wave, corroborated by statistical analysis. The relationship between SUHI and wind speed and direction are stronger during heat wave periods. Numerous studies describe such an intensification of the SUHI in the early hours of the morning and at night (Ackerman and Knox 2012; Li and Bou-Zeid 2013; Li et al. 2015; Ramamurthy and Bou-Zeid 2017; Jiang et al. 2019; An et al. 2020), thus validating the data obtained in this investigation.

According to our data, an average urban area in southern Spain would be affected by the SUHI phenomenon under normal environmental conditions to the extent of $85.23 \%$ in inland cities and $56.76 \%$ in coastal cities. The average urban surface affected by the SUHI phenomenon under heat wave conditions would be $15.66 \%$ greater, when compared to periods of normal environmental conditions. Still, this increase is uneven: $22.67 \%$ for coastal cities and $8.65 \%$ for inland cities. Research by other authors (Lemonsu et al. 2015; Ward et al. 2016; Carvalho et al. 2017; Jiang et al. 2019) presenting similar values comes to support the results obtained here.

\section{Conclusions}

In this work, the LST and SUHI were studied by analyzing Sentinel day and night images of the eight capitals of Andalusia (southern Spain) both in periods of normal environmental conditions and in periods of heat wave, during the years 2019 and 2020. A statistically significant relationship between the two variables is evidenced.

Our results detect mean LSTs based on Sentinel day and night in inland cities-both under normal environmental conditions and in periods of heat wave - that are higher than the mean LSTs of coastal cities. In turn, the average LSTs obtained with Sentinel day and night products for both urban and rural areas are intensified under heat wave environmental conditions, the increase being greater with Sentinel day in coastal cities, and with Sentinel night in inland cities.

The mean SUHI obtained with Sentinel day during the entire study period for the capitals of the Andalusian provinces showed negative values, whereas the mean SUHI obtained with Sentinel night showed positive values. This suggests that urban areas are at lower temperatures in the morning than neighboring rural areas, a phenomenon known as urban cooling island. Then, during the evening, the urban areas are at higher temperatures than the adjacent rural areas, producing an urban heat island. During heat wave periods, an intensification of the SUHI obtained with Sentinel day and night is detected for both inland cities and coastal cities, but it is greater for coastal cities with Sentinel day, and for inland cities with Sentinel night.

Within the scope of the environmental factors studied, our results attest to a positive and statistically significant relationship between SUHI and solar radiation, and between SUHI and the direction of the wind, intensified in periods of heat wave as compared to periods of normal environmental conditions. Wind speed turns out to be a positive and statistically significant variable, but only in periods of normal conditions and according to the data from Sentinel night images.

Our results detect that the surface of the urban area affected by the SUHI phenomenon under normal environmental conditions is greater for inland cities than for coastal cities. Notwithstanding, under heat wave conditions, the intensified SUHI entails a larger surface area, this phenomenon being greater for coastal cities than for inland cities.

Supplementary Information The online version contains supplementary material available at https://doi.org/10.1007/s41748-021-00268-9.

Author contributions Not applicable as there is only one author.

Funding Funding for open access charge: Universidad de Granada / CBUA.

Availability of data and material (data transparency) Not applicable.

Code availability (software application or custom code) Not applicable.

\section{Declarations}

Conflict of interest The author declares that there are no conflicts of interest regarding the publication of this paper.

Ethics approval The author indicates that all the ethical principles governing the publication of a research article in a journal have been followed.

Consent to participate The author agrees to participate in the review process and subsequent publication in the event of such an event.

Consent for publication If the article is accepted, the author consents to the publication and transfer of the information to the journal.

Open Access This article is licensed under a Creative Commons Attribution 4.0 International License, which permits use, sharing, adaptation, distribution and reproduction in any medium or format, as long as you give appropriate credit to the original author(s) and the source, provide a link to the Creative Commons licence, and indicate if changes were made. The images or other third party material in this article are 
included in the article's Creative Commons licence, unless indicated otherwise in a credit line to the material. If material is not included in the article's Creative Commons licence and your intended use is not permitted by statutory regulation or exceeds the permitted use, you will need to obtain permission directly from the copyright holder. To view a copy of this licence, visit http://creativecommons.org/licenses/by/4.0/.

\section{References}

Ackerman SA, Knox J (2012) Meteorology: Understanding the Atmosphere. Jones \& Bartlett Learning, Sudbury

Alcock I, White MP, Lovell R, Higgins SL, Osborne NJ, Husk K, Wheeler BW (2015) What accounts for "England's green and pleasant land"? A panel data analysis of mental health and land cover types in rural England. Landsc Urban Plan 142:38-46. https://doi.org/10.1016/j.landurbplan.2015.05.008

Ali G, Abbas S, Qamer FM, Wong MS, Rasul G, Irteza SM, Shahzad N (2021) Environmental impacts of shifts in energy, emissions, and urban heat island during the COVID-19 lockdown across Pakistan. J Clean Prod 291:125806. https://doi.org/10.1016/j. jclepro.2021.125806

An N, Dou J, González-Cruz JE, Bornstein RD, Miao S, Li L (2020) An observational case study of synergies between an intense heat wave and the urban heat island in Beijing. $J$ Appl Meteorol Climatol 59:605-620. https://doi.org/10.1175/ JAMC-D-19-0125.1

Anjos M, Targino AC, Krecl P, Oukawa GY, Braga RF (2020) Analysis of the urban heat island under different synoptic patterns using local climate zones. Build Environ. https://doi.org/10.1016/j. buildenv.2020.107268

Ao X, Wang L, Zhi X, Gu W, Yang H, Li D (2019) Observed synergies between urban heat islands and heat waves and their controlling factors in Shanghai, China. J Appl Meteorol Climatol 58:19551972. https://doi.org/10.1175/JAMC-D-19-0073.1

Arnfield AJ (2003) Two decades of urban climate research: A review of turbulence, exchanges of energy and water, and the urban heat island. Int J Climatol 23:1-26. https://doi.org/10.1002/joc.859

Avdan U, Jovanovska G (2016) Algorithm for automated mapping of land surface temperature using LANDSAT 8 satellite data. J Sens. https://doi.org/10.1155/2016/1480307

Barbieri T, Despini F, Teggi S (2018) A multi-temporal analyses of Land Surface Temperature using Landsat- 8 data and open source software: the case study of Modena, Italy. Sustainability (switzerland). https://doi.org/10.3390/su10051678

Basara JB, Basara HG, Illston BG, Crawford KC (2010) The Impact of the Urban Heat Island during an Intense Heat Wave in Oklahoma City. Adv Meteorol 2010:1-10. https://doi.org/10.1155/ 2010/230365

Carvalho D, Martins H, Marta-Almeida M, Rocha A, Borrego C (2017) Urban resilience to future urban heat waves under a climate change scenario: a case study for Porto urban area (Portugal). Urban Climate 19:1-27. https://doi.org/10.1016/j.uclim.2016. 11.005

Chen Y, Li X, Zheng Y, Guan Y, Liu X (2011) Estimating the relationship between urban forms and energy consumption: A case study in the Pearl River Delta, 2005-2008. Landsc Urban Plan 102(1):33-42. https://doi.org/10.1016/j.landurbplan.2011.03.007

Chiang S, Ivan N (2020) Mapping and Tracking Forest Burnt Areas in the Indio Maiz Biological Reserve Using Sentinel-3 SLSTR and VIIRS-DNB Imagery. Sensors (Switzerland) 19

Coppo P, Ricciarelli B, Brandani F, Delderfield J, Ferlet M, Mutlow C, Munro G, Nightingale T, Smith D, Bianchi S, Nicol P,
Kirschstein S, Hennig T, Engel W, Frerick J, Nieke J (2010) SLSTR: a high accuracy dual scan temperature radiometer for sea and land surface monitoring from space. J Mod Opt 57:18151830. https://doi.org/10.1080/09500340.2010.503010

Coumou D, Robinson A, Rahmstorf S (2013) Global increase in record-breaking monthly-mean temperatures. Clim Change 118:771-782. https://doi.org/10.1007/s10584-012-0668-1

Cramer W, Guiot J, Fader M, Garrabou J, Gattuso JP, Iglesias A, Lange MA, Lionello P, Llasat MC, Paz S, Peñuelas J, Snoussi M, Toreti A, Tsimplis MN, Xoplaki E (2018) Climate change and interconnected risks to sustainable development in the Mediterranean. Nat Clim Change 8:972-980. https://doi.org/10.1038/ s41558-018-0299-2

Das N, Sutradhar S, Ghosh R, Mondal P (2021) Asymmetric nexus between air quality index and nationwide lockdown for COVID19 pandemic in a part of Kolkata metropolitan. India Urban Clim 36:100789. https://doi.org/10.1016/j.uclim.2021.100789

De Boeck HJ, Dreesen FE, Janssens IA, Nijs I (2010) Climatic characteristics of heat waves and their simulation in plant experiments. Glob Change Biol 16:1992-2000. https://doi.org/10.1111/j.13652486.2009.02049.x

De Castro M, Gallardo C, Jylha K, Tuomenvirta H (2007) The use of a climate-type classification for assessing climate change effects in Europe from an ensemble of nine regional climate models. Clim Change 81(SUPPL. 1):329-341. https://doi.org/10.1007/ s10584-006-9224-1

Emmanuel R, Krüger E (2012) Urban heat island and its impact on climate change resilience in a shrinking city: the case of Glasgow, UK. Build Environ 53:137-149. https://doi.org/10.1016/j.build env.2012.01.020

Fang L, Tian C (2020) Construction land quotas as a tool for managing urban expansion. Landsc Urban Plann 195:103727. https://doi. org/10.1016/j.landurbplan.2019.103727

Feizizadeh B, Blaschke T (2013) Examining Urban heat Island relations to land use and air pollution: Multiple endmember spectral mixture analysis for thermal remote sensing. IEEE J Select Top Appl Earth Observ Remote Sens 6:1749-1756. https://doi.org/ 10.1109/JSTARS.2013.2263425

Founda D, Santamouris M (2017) Synergies between Urban Heat Island and Heat waves in Athens (Greece), during an extremely hot summer (2012). Sci Rep 7:1-11. https://doi.org/10.1038/ s41598-017-11407-6

Founda D, Pierros F, Petrakis M, Zerefos C (2015) Interdecadal variations and trends of the Urban Heat Island in Athens (Greece) and its response to heat waves. Atmos Res 161-162:1-13. https://doi. org/10.1016/j.atmosres.2015.03.016

Gallo K, Hale R, Tarpley D, Yu Y (2011) Evaluation of the relationship between air and land surface temperature under clear- and cloudy-sky conditions. J Appl Meteorol Climatol 50:767-775. https://doi.org/10.1175/2010JAMC2460.1

Gaur A, Eichenbaum MK, Simonovic SP (2018) Analysis and modelling of surface Urban Heat Island in 20 Canadian cities under climate and land-cover change. J Environ Manag 206:145-157. https://doi.org/10.1016/j.jenvman.2017.10.002

Ghosh S, Das A, Hembram TK, Saha S, Pradhan B, Alamri AM (2020) Impact of COVID-19 induced lockdown on environmental quality in four Indian megacities Using Landsat 8 OLI and TIRSderived data and Mamdani fuzzy logic modelling approach. Sustainability (switzerland) 12(13):1-24. https://doi.org/10. 3390/su12135464

Gregor GR, Felling M, Wolf T, Gosling S (2007) The social impacts of heat waves. Environmen. Ed., Bristol

Grumm RH (2011) The central European and Russian heat event of July-August 2010. Bull Am Meteorol Soc 92:1285-1296. https:// doi.org/10.1175/2011BAMS3174.1 
Guo A, Yang J, Xiao X, Xia J, Jin C, Li X (2020) Influences of urban spatial form on urban heat island effects at the community level in China. Sustain Cities Soc 53:101972. https://doi.org/10.1016/j. scs.2019.101972

House M, Santamouris M (2011) Advances in Building Energy Research Heat Island Research in Europe : the State of Heat Island Research in Europe : The State of the Art 37-41

Hu Y, Dai Z, Guldmann JM (2020) Modeling the impact of 2D/3D urban indicators on the urban heat island over different seasons: a boosted regression tree approach. J Environ Manag 266:110424. https://doi.org/10.1016/j.jenvman.2020.110424

Huang F, Zhan W, Wang ZH, Voogt J, Hu L, Quan J, Lui C, Zhang N, Lai J (2020) Satellite identification of atmospheric surface subsurface urban heat islands under clear sky. Remote Sens Environ 260:112039. https://doi.org/10.1016/j.rse.2020.112039

Jiang S, Lee X, Wang J, Wang K (2019) Amplified Urban Heat Islands during Heat Wave Periods. J Geophys Res Atmos 124:7797-7812. https://doi.org/10.1029/2018JD030230

Jiang P, Fu X, Fan Y, Klemeš J, Chen P, Ma S, Zhang W (2021) Spatial-temporal potential exposure risk analytics and urban sustainability impacts related to COVID-19 mitigation: a perspective from car mobility behaviour. J Clean Prod. https://doi. org/10.1016/j.jclepro.2020.123673

Karakuş CB (2019) The Impact of Land Use/Land Cover (LULC) Changes on Land Surface Temperature in Sivas City Center and Its Surroundings and Assessment of Urban Heat Island. Asia-Pac J Atmos Sci 55:669-684. https://doi.org/10.1007/ s13143-019-00109-w

Keramitsoglou I, Kiranoudis CT, Ceriola G, Weng Q, Rajasekar U (2011) Identification and analysis of urban surface temperature patterns in Greater Athens, Greece, using MODIS imagery. Remote Sens Environ 115:3080-3090. https://doi.org/10. 1016/j.rse.2011.06.014

Labra R (2014) Zero panel data guide. (Cátedra UA). file:///U:/Maguilera/Documentos Personales MAGUILERA/Master M3F/Trabajo Fin M3F/Revisión para paper/Referencias/Stata/16_Guia CERO para datos de panel_Un enfoque practico.pdf

Lai J, Zhan W, Huang F, Voogt J, Bechttel B, Allen M, Peng S, Hong F, Du P (2018) Identification of typical diurnal patterns for clear sky climatology of surface urban heat islands. Remote Sens Environ 217:203-230. https://doi.org/10.1016/j.rse.2018. 08.021

Lau NC, Nath MJ (2012) A model study of heat waves over North America: Meteorological aspects and projections for the twentyfirst century. J Clim 25:4761-4764. https://doi.org/10.1175/ JCLI-D-11-00575.1

Lemonsu A, Viguié V, Daniel M, Masson V (2015) Vulnerability to heat waves: Impact of urban expansion scenarios on urban heat island and heat stress in Paris (France). Urban Clim 14:586-605. https://doi.org/10.1016/j.uclim.2015.10.007

Lemus M, Martin J, Moreno MC, Lopez JA (2020) Estimating Barcelona's metropolitan daytime hot and cold poles using Landsat-8 Land Surface Temperature. Sci Total Environ 699:134307. https://doi.org/10.1016/j.scitotenv.2019.134307

Li D, Bou-Zeid E (2013) Synergistic interactions between urban heat islands and heat waves: the impact in cities is larger than the sum of its parts. J Appl Meteorol Climatol 52:2051-2064. https://doi. org/10.1175/JAMC-D-13-02.1

Li T, Meng Q (2018) A mixture emissivity analysis method for urban land surface temperature retrieval from Landsat 8 data. Landsc Urban Plan 179:63-71. https://doi.org/10.1016/j.landurbplan. 2018.07.010

Li J, Song C, Cao L, Zhu F, Meng X, Wu J (2011) Impacts of landscape structure on surface urban heat islands: a case study of Shanghai, China. Remote Sens Environ 115:3249-3263. https://doi.org/10. 1016/j.rse.2011.07.008
Li ZL, Tang BH, Wu H, Ren H, Yan G, Wan Z et al (2013) Satellitederived land surface temperature: current status and perspectives. Remote Sens Environ 131:14-37. https://doi.org/10.1016/j.rse. 2012.12.008

Li D, Sun T, Liu M, Yang L, Wang L, Gao Z (2015) Contrasting responses of urban and rural surface energy budgets to heat waves explain synergies between urban heat islands and heat waves. Environ Res Lett. https://doi.org/10.1088/1748-9326/ $10 / 5 / 054009$

Logan TM, Zaitchik B, Guikerma S, Nisbet A (2020) Night and day: The influence and relative importance of urban characteristics on remotely sensed land surface temperature. Remote Sens Environ 247:111861. https://doi.org/10.1016/j.rse.2020.111861

Luo M, Lau NC (2018) Increasing Heat Stress in Urban Areas of Eastern China: acceleration by Urbanization. Geophys Res Lett 45:13060-13069. https://doi.org/10.1029/2018GL080306

Mallick J, Rahman A, Singh CK (2013) Modeling urban heat islands in heterogeneous land surface and its correlation with impervious surface area by using night-time ASTER satellite data in highly urbanizing city, Delhi-India. Adv Space Res 52:639-655. https:// doi.org/10.1016/j.asr.2013.04.025

Mandal I, Pal S (2020) COVID-19 pandemic persuaded lockdown effects on environment over stone quarrying and crushing areas. Sci Total Environ 732:139281. https://doi.org/10.1016/j.scito tenv.2020.139281

McMillin LM (1975) Estimation of sea surface temperatures from two infrared window measurements with different absorption. J Geophys Res 80(36):5113-5117. https://doi.org/10.1029/JC080 i036p05113

Meehl GA, Tebaldi C (2004) More intense, more frequent, and longer lasting heat waves in the 21st century. Science 305:994-997. https://doi.org/10.1126/science.1098704

Nakajima K, Takane Y, Kikegawa Y, Furuta Y, Takamatsu H (2021) Human behaviour change and its impact on urban climate: Restrictions with the G20 Osaka Summit and COVID-19 outbreak. Urban Clim 35:100728. https://doi.org/10.1016/j.uclim. 2020.100728

Oke TR (1987) Boundary layer climates. Routledge, London

Pani SK, Lin NH, RavindraBabu S (2020) Association of COVID-19 pandemic with meteorological parameters over Singapore. Sci Total Environ 740:140112. https://doi.org/10.1016/j.scitotenv. 2020.140112

Poumadère M, Mays C, Le Mer S, Blong R (2005) The 2003 heat wave in France: dangerous climate change here and now. Risk Anal 25:1483-1494. https://doi.org/10.1111/j.1539-6924.2005. 00694.x

Prikaziuk E, van der Tol C (2019) Global sensitivity analysis of the SCOPE model in Sentinel-3 Bands: thermal domain focus. Remote Sens. https://doi.org/10.3390/rs11202424

Qui T, Song C, Clark J, Seyednasrollah B, Rathnayaka N, Li J (2020) Understanding the continuous phenological delepment at daily time step with a Bayesian hierarchical space time model: impacts of climate change and extreme weather events. Remote Sens Environ 247:111956. https://doi.org/10.1016/j.rse.2020.111956

Ramamurthy P, Bou-Zeid E (2017) Heatwaves and urban heat islands: a comparative analysis of multiple cities. J Geophys Res 122:168178. https://doi.org/10.1002/2016JD025357

Remedios J, Emsley S (2012) Sentinel-3 Optical Products and Algorithm Definition Land Surface Temperature. 24

Robine JM, Cheung SLK, Le Roy S, Van Oyen H, Griffiths C, Michel JP, Herrmann FR (2008) Death toll exceeded 70,000 in Europe during the summer of 2003. C R Biol 331:171-178. https://doi. org/10.1016/j.crvi.2007.12.001

Rongali G, Keshari AK, Gosain AK, Khosa R (2018) A mono-window algorithm for land surface temperature estimation from landsat 8 
thermal infrared sensor data: a case study of the beas river basin, India. Pertanika J Sci Technol 26:829-840

Roy S, Pandit S, Eva EA, Bagmar MSH, Papia M, Banik L, Dube T, Rahman F, Razi MA (2020) Examining the nexus between land surface temperature and urban growth in Chattogram Metropolitan Area of Bangladesh using long term Landsat series data. Urban Clim 32:100593. https://doi.org/10.1016/j.uclim. 2020.100593

Ruescas AB, Danne O, Fomferra N, Brockmann C (2016) The land surface temperature synergistic processor in beam: a prototype towards sentinel-3. Data 1:1-14. https://doi.org/10.3390/data1 030018

Saaroni H, Amorim JH, Hiemstra JA, Pearlmutter D (2018) Urban Green Infrastructure as a tool for urban heat mitigation: Survey of research methodologies and findings across different climatic regions. Urban Clim 24:94-110. https://doi.org/10.1016/j.uclim. 2018.02.001

Santamouris M (2020) Recent progress on urban overheating and heat island research. Integrated assessment of the energy, environmental, vulnerability and health impact. Synergies with the global climate change. Energy Build. https://doi.org/10.1016/j. enbuild.2019.109482

Schwarz N, Lautenbach S, Seppelt R (2011) Exploring indicators for quantifying surface urban heat islands of European cities with MODIS land surface temperatures. Remote Sens Environ 115:3175-3186. https://doi.org/10.1016/j.rse.2011.07.003

Scott AA, Waugh DW, Zaitchik BF (2018) Reduced Urban Heat Island intensity under warmer conditions. Environ Res Lett. https://doi. org/10.1088/1748-9326/aabd6c

Sejati AW, Buchori I, Rudiarto I (2019) The spatio-temporal trends of urban growth and surface urban heat islands over two decades in the Semarang Metropolitan Region. Sustain Cities Soc 46:101432. https://doi.org/10.1016/j.scs.2019.101432

Semenza J, Rubin C, Falter K, Selanikio J, Flanders W, Howe H, Wilhelm J (1996) Heat-related deaths during the July 1995 heat wave in Chicago. N Engl J Med 335(2):86-90. https://doi.org/10.1056/ nejm199607113350203

Shafizadeh H, Weng Q, Liu H, Valavi R (2020) Modeling the spatial variation of urban land surface temperature in relation to environmental and anthropogenic factors: a case study of Tehran, Iran. Gisci Remote Sens 57:483-496. https://doi.org/10.1080/ 15481603.2020.1736857

Sobrino JA, Jiménez JC, Sòria G, Ruescas AB, Danne O, Brockmann C, Ghent D, Remedios J, North P, Merchant C, Berger M, Mathieu PP, Göttsche FM (2016) Synergistic use of MERIS and AATSR as a proxy for estimating Land Surface Temperature from Sentinel-3 data. Remote Sens Environ 179:149-161. https:// doi.org/10.1016/j.rse.2016.03.035

Song J, Lin T, Li X, Prishchepov AV (2018) Mapping urban functional zones by integrating very high spatial resolution remote sensing imagery and points of interest: a case study of Xiamen. China Remote Sens. https://doi.org/10.3390/rs10111737

Song J, Chen W, Zhang J, Huang K, Hou B, Prishchepov AV (2020) Effects of building density on land surface temperature in China: Spatial patterns and determinants. Landsc Urban Plan 198:103794. https://doi.org/10.1016/j.landurbplan.2020.103794

Srivastava PK, Majumdar TJ, Bhattacharya AK (2009) Surface temperature estimation in Singhbhum Shear Zone of India using Landsat-7 ETM+ thermal infrared data. Adv Space Res 43:15631574. https://doi.org/10.1016/j.asr.2009.01.023

Srivastava AK, Bhoyar PD, Kanawade VP, Devara PCS, Thomas A, Soni VK (2021) Improved air quality during COVID-19 at an urban megacity over the Indo-Gangetic Basin: from stringent to relaxed lockdown phases. Urban Clim 36:100791. https://doi.org/ 10.1016/j.uclim.2021.100791
Stewart ID, Oke TR (2012) Local climate zones for urban temperature studies. Bull Am Meteorol Soc 93:1879-1900. https://doi.org/ 10.1175/BAMS-D-11-00019.1

Sun Y, Zhang X, Zwiers FW, Song L, Wan H, Hu T, Yin H, Ren G (2014) Rapid increase in the risk of extreme summer heat in Eastern China. Nat Clim Change 4:1082-1085. https://doi.org/ $10.1038 /$ nclimate 2410

Tan M, Li X (2015) Quantifying the effects of settlement size on urban heat islands in fairly uniform geographic areas. Habitat Int 49:100-106. https://doi.org/10.1016/j.habitatint.2015.05.013

Tewari M, Yang J, Kusaka H, Salamanca F, Watson C, Treinish L (2019) Interaction of urban heat islands and heat waves under current and future climate conditions and their mitigation using green and cool roofs in New York City and Phoenix, Arizona. Environ Res Lett. https://doi.org/10.1088/1748-9326/aaf431

Toro R, Catalán F, Urdanivia FR, Rojas JP, Manzano CA, Seguel R, Gallardo L, Osses M, Pantoja N, Leiva-Guzman MA (2021) Air pollution and COVID-19 lockdown in a large South American city: Santiago Metropolitan Area Chile. Urban Clim. https://doi. org/10.1016/j.uclim.2021.100803

Tsou J, Zhuang J, Li Y, Zhang Y (2017) Urban Heat Island Assessment Using the Landsat 8 Data: a case study in Shenzhen and Hong Kong. Urban Sci 1:10. https://doi.org/10.3390/urbansci1010010

UNO (2021) June ends with exceptional heat. [WWW Document]. URL https://public.wmo.int/en/media/news/june-ends-excep tional-heat

Valor E, Meneu V, Caselles V (2001) Daily air temperature and electricity load in Spain. J Appl Meteorol 40:1413-1421. https://doi. org/10.1175/1520-0450(2001)040

Van Hove LWA, Jacobs CMJ, Heusinkveld BG, Elbers JA, Van Driel BL, Holtslag AAM (2015) Temporal and spatial variability of urban heat island and thermal comfort within the Rotterdam agglomeration. Build Environ 83:91-103. https://doi.org/10. 1016/j.buildenv.2014.08.029

Venter Z, Brousse O, Esau I, Meier F (2020) Hyperlocal mapping of urban air temperature using remote sensing and crowdsourced weather data. Remote Sens Environ 242:111791. https://doi.org/ 10.1016/j.rse.2020.111791

Wan Z (2013) New refinements and validation of the collection-6 MODIS land-surface temperature/emissivity product. Remote Sens Environ 140:36-45. https://doi.org/10.1016/j.rse.2013.08. 027

Wang J, Ouyang W (2017) Attenuating the surface Urban Heat Island within the Local Thermal Zones through land surface modification. J Environ Manag 187:239-252. https://doi.org/10.1016/j. jenvman.2016.11.059

Wang J, Huang B, Fu D, Atkinson PM, Zhang X (2016) Response of urban heat island to future urban expansion over the BeijingTianjin-Hebei metropolitan area. Appl Geogr 70:26-36. https:// doi.org/10.1016/j.apgeog.2016.02.010

Wang K, Jiang S, Wang J, Zhou C, Wang X, Lee X (2017) Journal of geophysical research. J Geophys Res Atmos 122:2131-2154. https://doi.org/10.1002/2016JD025304

Ward K, Lauf S, Kleinschmit B, Endlicher W (2016) Heat waves and urban heat islands in Europe: a review of relevant drivers. Sci Total Environ 569-570:527-539. https://doi.org/10.1016/j.scito tenv.2016.06.119

Wu C, Li J, Wang C, Song C, Chen Y, Finka M, La Rosa D (2019) Understanding the relationship between urban blue infrastructure and land surface temperature. Sci Total Environ. https://doi.org/ 10.1016/j.scitotenv.2019.133742

Xia J, Tu K, Yan Z, Qi Y (2016) The super-heat wave in eastern China during July-August 2013: a perspective of climate change. Int J Climatol 36:1291-1298. https://doi.org/10.1002/joc.4424 
Xoplaki E, González JF, Gyalistras D, Luterbacher J, Rickli R, Wanner H (2003) Interannual summer air temperature variability over Greece and its connection to the large-scale atmospheric circulation and Mediterranean SSTs 1950-1999. Clim Dyn 20:537-554. https://doi.org/10.1007/s00382-002-0291-3

Yang C, Wang R, Zhang S, Ji C, Fu X (2019) Characterizing the hourly variation of urban heat islands in a snowy climate city during summer. Int J Environ Res Public Health. https://doi.org/10. 3390/ijerph16142467

Yang C, Yan F, Zhang S (2020a) Comparison of land surface and air temperatures for quantifying summer and winter urban heat island in a snow climate city. J Environ Manag 265:110563. https://doi.org/10.1016/j.jenvman.2020.110563

Yang J, Zhou J, Göttsche F-M, Long Z, Ma J, Luo R (2020b) Investigation and validation of algorithms for estimating land surface temperature from Sentinel-3 SLSTR data. Int J Appl Earth Obs Geoinf 91:102136. https://doi.org/10.1016/j.jag.2020.102136

Yao R, Wang L, Huang X, Zhang W, Li J, Niu Z (2018) Interannual variations in surface urban heat island intensity and associated drivers in China. J Environ Manag 222:86-94. https://doi.org/10. 1016/j.jenvman.2018.05.024

Yoon D, Cha DH, Lee G, Park C, Lee MI, Min KH (2018) Impacts of Synoptic and Local Factors on Heat Wave Events Over Southeastern Region of Korea in 2015. J Geophys Res Atmos 123:12081-12096. https://doi.org/10.1029/2018JD029247

Zakšek K, Podobnikar T, Oštir K (2005) Solar radiation modelling. Comput Geosci 31:233-240. https://doi.org/10.1016/j.cageo. 2004.09.018

Zhao L, Lee X, Smith RB, Oleson K (2014) Strong contributions of local background climate to urban heat islands. Nature 511:216219. https://doi.org/10.1038/nature13462

Zhao L, Oppenheimer M, Zhu Q, Baldwin JW, Ebi KL, Bou-Zeid E, Guan K, Liu X (2018) Interactions between urban heat islands and heat waves. Environ Res Lett. https://doi.org/10.1088/17489326/aa9f73

Zhou D, Zhao S, Zhang L, Sun G, Liu Y (2015) The footprint of urban heat island effect in China. Sci Rep 5:2-12. https://doi.org/10. 1038/srep11160 